\title{
Climate-Glacier Dynamics and Topographic Forcing in the Karakoram Himalaya: Concepts, Issues and Research Directions
}

\author{
Iliyana D. Dobreva ${ }^{1,2,3, *}$, Michael P. Bishop ${ }^{1,3}$ and Andrew B. G. Bush ${ }^{4}$ \\ 1 Department of Geography, Texas A\&M University, College Station, TX 77843, USA; \\ michael.bishop@tamu.edu \\ 2 Department of Soil and Crop Sciences, Texas A\&M University, College Station, TX 77843, USA \\ 3 Center for Geospatial Science, Applications and Technology, Texas A\&M University, \\ College Station, TX 77843, USA \\ 4 Department of Earth and Atmospheric Sciences, University of Alberta, Edmonton, AB T6G 2E3, Canada; \\ abush@ualberta.ca \\ * Correspondence: iliyanad@tamu.edu \\ Academic Editor: Daene C. McKinney \\ Received: 31 March 2017; Accepted: 1 June 2017; Published: 6 June 2017
}

\begin{abstract}
Understanding climate-glacier dynamics in High Mountain Asia is of critical importance to address issues including water resources, sea-level rise, mountain geodynamics, natural hazards and ecosystem sustainability. The Karakoram Himalaya is arguably the least understood region, given its extreme topography, climate-system coupling, and advancing and surge-type glaciers that exhibit complex flow patterns. Glacier fluctuations in the Karakoram Himalaya are highly variable in space and time because of numerous controlling factors, including the westerlies, the Indian summer monsoon, various teleconnections, topographic effects, glacier debris-cover characteristics, glacier dynamics, and geological conditions. The influence of the integrative coupling of forcing factors, however, has not been adequately assessed for characterizing the glaciers in the Karakoram Himalaya. Given the scarcity of in-situ data and the difficulty of conducting fieldwork on these glaciers, recent research has focused on utilizing remote sensing, geospatial technologies, and scientific modeling to obtain baseline information about the state of glaciers in the region. This review summarizes our current knowledge of glaciers, climate-glacier interaction, and topographic forcing in the Karakoram Himalaya, and demonstrates the complexities in mountain geodynamics that influence climate-glacier dynamics. Innovative analysis is also presented in support of our review and discussion.
\end{abstract}

Keywords: glaciers; climate; topography; teleconnections; Karakoram Himalaya; High Mountain Asia

\section{Introduction}

Various Earth systems are in a state of transition due to climate change, and this has resulted in ecosystem migration, an increase in natural hazards, and water resource issues [1-9]. Changes in the Earth's cryosphere are one indicator of climate change [10], as the cryosphere is regulated on the basis of energy and water fluxes. Arctic sea ice and Northern Hemisphere snow/ice cover are decreasing, the Antarctic and Greenland ice sheets are losing mass, and many glaciers worldwide are receding [10-19]. Furthermore, climate change increases human vulnerability due to temperature and precipitation anomalies that can lead to events such as heat waves, intensified drought, storms, sea-level rise, and flooding [6,20-26]. The Karakoram Mountain Range in Pakistan features some of the largest glaciers on Earth outside of the Polar Regions. Most of these glaciers are heavily debris-covered and avalanche-fed, and some of them appear to be departing from the global trend of recession [27-34]. Moreover, a controversial and incorrect statement about the disappearance of Himalayan glaciers by the year 
2035 [35-37] indicated the lack of understanding of glacier system processes in the Himalaya and the Karakoram. Even though mass balance projections for Karakoram glaciers have been performed (e.g., [38]), some studies found that a number of the Karakoram glaciers are oscillating due to surge mechanisms and ablation/accumulation [27,39].

Therefore, the assumption of linear change over time is not a reasonable one given that approximately $50 \%$ of Karakoram glacier termini are stable or are advancing, and may exhibit positive mass balance conditions, in contrast to the other $50 \%$ which are receding like the glaciers of the central and eastern Himalaya [39]. Basic knowledge of Karakoram glaciers comes primarily from remote sensing observations and inventory studies [40-43]. Various techniques and methodological approaches have been used for glacier assessment and mapping [42,44-46]. Advanced geospatial technologies have yet to be effectively used to characterize scale-dependencies of parameters and surface processes that govern climate-glacier dynamics [47,48]. Similarly, high-resolution climate simulations have yet to provide an understanding of climate-system interactions and teleconnections, although correlations between large scale atmospheric oscillations, such as the North Atlantic Oscillation (NAO) and the Southern Oscillation (SO), with precipitation in the Himalaya have been found [49-51]. Topography imposes constraints on microclimatic conditions and glacier dynamics [52], and systematic and comprehensive research is urgently needed to integrate climate, topographic and debris cover information to understand various forcing factors [27,48,53]. Moreover, the Karakoram Himalaya is an ideal location for studying complex climate-glacier dynamics, as the region has historically experienced dramatic climatic change coupled with extreme topography [54-56]. Unfortunately, accurate information on orographic precipitation, energy fluxes, multi-scale topographic properties, glacier mass loading, debris cover characteristics, and ablation patterns is generally not available at appropriate spatio-temporal scales. Furthermore, our ability to assess glacier sensitivity to climate forcing is full of uncertainties, as debris covered glaciers are difficult to model $[57,58]$, and they are mostly assumed to be less impacted by atmospheric warming [59].

Given the complexity and uncertainties associated with numerous aspects of climate-glacier dynamics and surface processes, the purpose of this article is to review our current understanding of climate-glacier dynamics in the Karakoram Himalaya; a region of known spatial anomalies related to climate, surface processes, tectonics and glacier fluctuations. We identify numerous concepts and issues associated with understanding complex dynamics, and provide insights into how the glaciers in this region may be responding to climate change from a mountain geodynamics perspective. We emphasize the role of topography in understanding numerous processes and demonstrate the need for new research directions by addressing unresolved issues. We accomplish this by reviewing climate system dynamics, climate and topography, climate-glacier dynamics and surface processes in the context of a coupled mountain geodynamics system. Innovative analysis demonstrating the importance of the topography on climate is also presented.

\section{Study Area}

Our characterization of the Karakoram focuses on the Central Karakoram in Pakistan (Figure 1). With over $7 \mathrm{~km}$ of topographic relief, the region exhibits high magnitude processes. It is also heavily glaciated with varying estimates of glaciated area according to different studies-16,600 $\mathrm{km}^{2}$ [14], $21,771 \mathrm{~km}^{2}$ [60], and 21,000 $\mathrm{km}^{2}$. Glaciers are easily identified on the false-color composite of Landsat 8 images in Figure 1. The greatest altitudes are in the southwestern portion of our region near K2 peak and the lowest altitudes are in the southwestern portion of the region associated with the Indus River valley. The Karakoram mountain range was formed due to the collision of the Indian and Asian plates, and it is highly eroded [27]. This region includes the large Batura, Hispar, Baltoro, and Biafo glaciers, as well as numerous smaller and intermediate-sized glaciers. Most of the glaciers in the area are heavily debris-covered with larger glaciers exhibiting numerous ice cliffs and supraglacial lakes. The region is climatically influenced by the westerlies, the Indian summer monsoon and The El Niño Southern Oscillation (ENSO). 
Advancing glaciers and positive mass balance conditions in the Karakoram are related to the region's unique snowfall regime [61]. Given a strong orographic effect, the maximum precipitation is deposited above the snow line creating favorable conditions for glacier formation and relatively high ice fluxes contributing to some of the largest glaciers outside of the Polar regions [61]. Extreme relief, steep slopes and high magnitude erosion processes and sediment fluxes generate significant debris loads over glaciers of all sizes, thus significantly altering the ablation dynamics of these glaciers $[58,59,62]$.

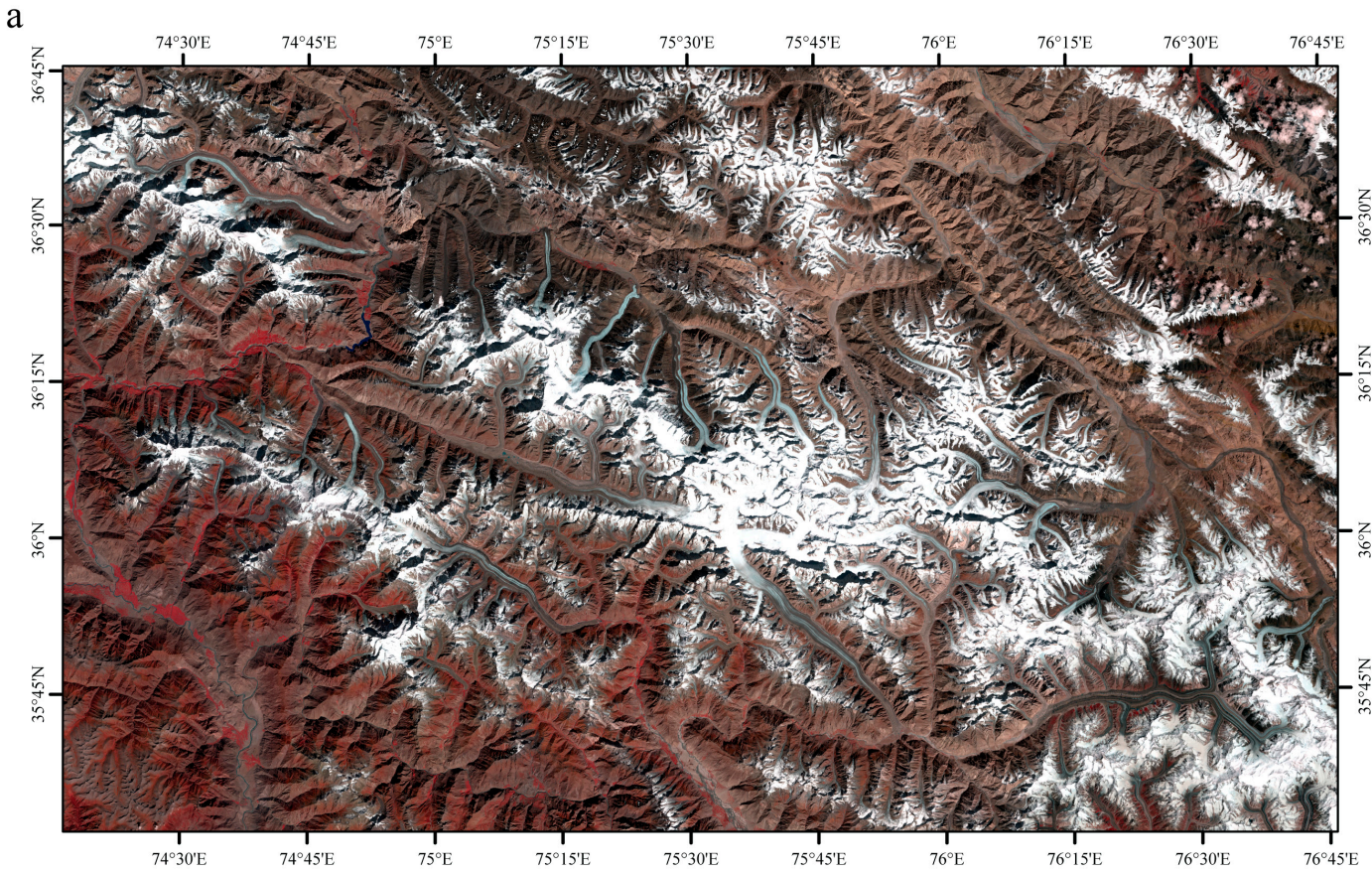

b

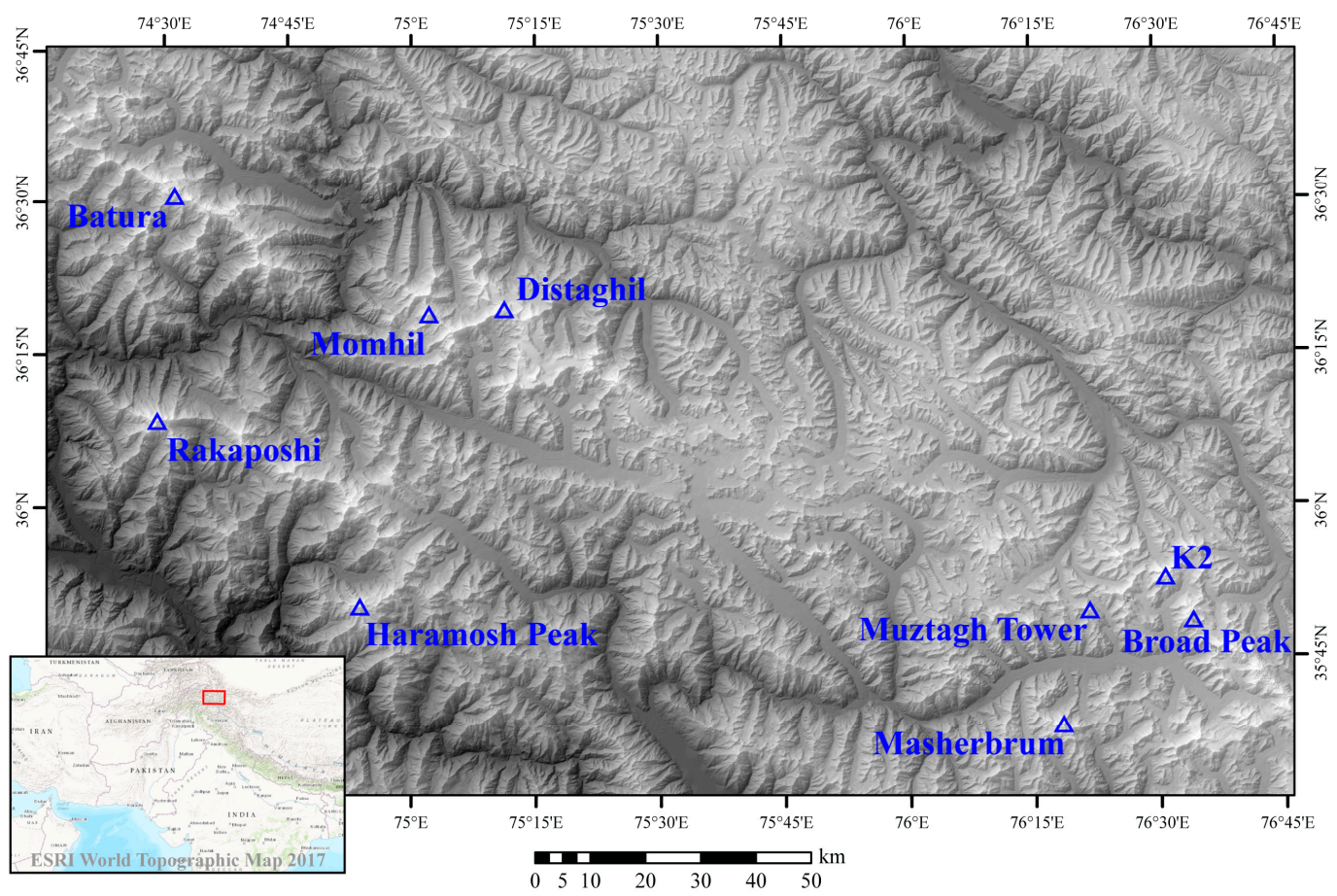

Figure 1. This map of the Karakoram Himalaya displays: a Landsat 8 false-color composite image (a); and a Shuttle Radar Topographic Mapping Mission (SRTM) based analytical shaded-relief map of the Karakoram with major peaks identified (b). 


\section{Climate}

\subsection{Climate Systems}

The Karakoram Himalaya is characterized by a mid-latitude high-mountain climate with cold winters and mild summers [63]. Most of the precipitation over the area is due to winter western disturbances [64,65], even though western disturbances likely contribute during other times of the year. The contribution by western disturbances can, however, be influenced by other geographically remote factors through teleconnections $[56,66]$. The Indian summer monsoon, which is a part of the larger Asian-Australian monsoon system [67], is also an important contributor to precipitation in the region [68,69]. A third synoptic-scale climate feature affecting the region is the Tibetan Anticyclone, which is strong during the summer and affects the intrusion of the Indian summer monsoon into the Karakoram Himalaya [70,71].

\subsubsection{Midlatitude Subtropical Westerly Jet and Westerly Disturbances}

The midlatitude Subtropical Westerly Jet (also referred to as the westerlies) is a general circulation wind belt, driven by the thermal gradient between approximately $30^{\circ}$ latitude and the poles in both hemispheres [72]. Energy transport occurs due to cyclones and anticyclones which are generated through instability of the Jet as well as its interaction with the thermal and topographic characteristics of the underlying land masses and ocean [72]. Western disturbances can also be generated by the notch between the western Himalaya and the Hindu Kush mountains [73], resulting in eastward-propagating extratropical cyclones that are prevalent over the Karakoram Himalaya mainly during the winter and spring [64,65], but that are also observed during the summer [56,66].

The cold fronts of these cyclones propagate into the warm tropical air mass of the Indian subcontinent. Precipitated water from these storm systems was originally evaporated from the Mediterranean, Red, Persian, Caspian, and Arabian Seas [65,74]. Even more significantly, the cyclones interact with the Karakoram Himalaya topography, producing orographic precipitation that sustains the glaciers in the region $[75,76]$. The influence of the western disturbances in the Karakoram Himalaya does not have a specific geographic limit. Some research [77], however, delineates climate geographic regions over Pakistan through climate station data for the period 1951-2000. This work shows that the region mainly influenced by the westerlies is north of $35^{\circ} \mathrm{N}$, and the area to the south is mostly affected by the Indian summer monsoon. It should be noted that this climate dataset consists of only a limited number of stations at high altitude.

The Karakoram is primarily dominated by the westerlies, with dominant snowfall occurring in winter and spring, and with observed increases in winter precipitation over time $[39,49,78]$. Teleconnections influence the circulation, and therefore regulate precipitation, particularly if they enhance the influence of the westerly jet [65,79-81]. Simulation studies indicate that precipitation forcing could dominate until 2050, after which enhanced internal convective motion due to debris cover and increasing temperatures will dominate, suggesting that Karakoram glaciers will eventually exhibit negative mass balance $[58,81]$.

\subsubsection{Indian Summer Monsoon}

The Karakoram is also heavily influenced by the Indian summer monsoon, part of the broader Asian-Australian monsoon system. The monsoon is driven by seasonal contrasts in surface temperature between the ocean and land surfaces. Related to the comparatively stable ocean temperature, land-surface temperature varies seasonally being relatively hot during the summer and relatively cold during the winter. The resulting pressure gradients drive the seasonal monsoon winds, with a reversal of the winds during the summer (as compared to winter) when the pressure gradient reverses. Monsoon rainfall therefore varies significantly over the dry and wet seasons. In the northern hemisphere summer, the monsoon extends from the Arabian Sea north and eastward into southern and southeastern Asia. During the southern hemisphere summer, it extends in the opposite direction 
westward towards Africa [82]. The importance of the Indian summer monsoon for Karakoram glaciers is that it generates topographically induced summer precipitation over much of Pakistan and India with intrusions into the Karakoram.

The strength of the monsoon plays a crucial role in regulating precipitation and snow accumulation [81,83]. Monsoon incursions penetrate into the Karakoram during the summer months [84], and teleconnections between tropical sea-surface temperatures and the strength of the monsoon have been shown to potentially dominate orbital forcing [66]. The monsoon is thought to be responsible for the observed decreases in summer temperatures due to documented increase in cloud cover [85], and thus summer cloudiness may be a contributing factor to snow accumulation. Research has validated the summertime cooling trend since the 1960s [50,86]. From a topographic perspective, the monsoon penetrates into the Karakoram (via glacial valley pathways) and into the Hunza region and easterly over the Baltoro Glacier near K2 Mountain (Figure 2).

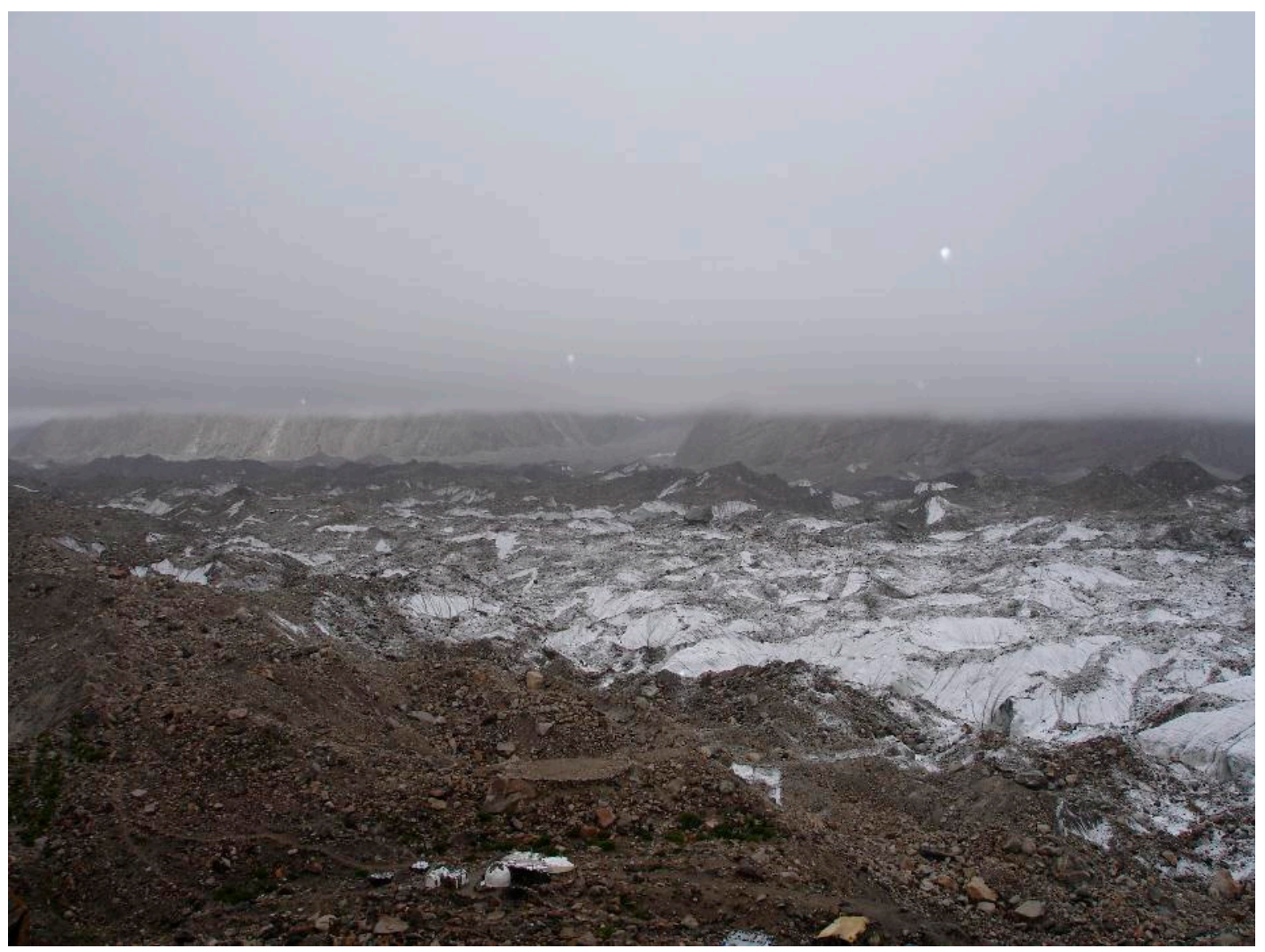

Figure 2. Monsoon snowfall on the Baltoro glacier, as seen from Urdokas (photo credit: Andrew G.B. Bush, 2005).

\subsubsection{Tibetan Anticyclone}

The Indian summer monsoon reaches deeper into the region when there is a weakening of the Tibetan anticyclone, which is a synoptic scale feature centered over Tibet in the summer. The South Asian anticyclone is an upper tropospheric subtropical anticyclone that migrates from the Bay of Bengal in the winter to the Tibetan Plateau in the summer [87]. The summer mode is referred to as the Tibetan anticyclone [87] or Inner Asian high-pressure system [69]. It has a warm core and affects both regional weather conditions and large-scale atmospheric circulation (e.g., [88]). Relevant to the study of Karakoram glaciers is that, during the irregular weakening of the Tibetan Anticyclone, the Indian summer monsoon reaches the Karakoram and deposits large amounts of precipitation [70,71]. 


\subsection{Teleconnections}

Teleconnections have large influence on the climate patterns and dynamics over south Asia, particularly, those arising from disturbances in the tropical Pacific Ocean (e.g., [66,67]). ENSO, for example, exhibits global effects through the planetary wave propagation that arises from surface forcing caused by sea surface temperature anomalies in the central and eastern tropical Pacific Ocean (e.g., [89]). Additionally, the characteristics of ENSO can be altered by midlatitude processes [90].

\subsubsection{El Niño-Southern Oscillation (ENSO)}

Climate research shows that the intensity of the monsoon is negatively correlated with ENSO, such that during El Niño the monsoon is generally weaker but during La Niña it is stronger e.g., [91]. Weakening of the Indian summer monsoon produces less precipitation and droughts whereas the stronger La Niña monsoon produces enhanced precipitation [92,93]. The observed correlation between ENSO and the monsoon does not, however, guarantee a weakening of the Indian summer monsoon during an El Niño event due to the statistical nature of the relationship [80,93,94]. Elucidating a clearer understanding of the dynamical relationship between ENSO and the monsoon is important, as it is one of the important factors governing precipitation over the glaciers in the Karakoram Himalaya.

The westerlies are also strongly influenced by ENSO. During El Niño, a weaker monsoon implies that the influence of the westerlies over the Karakoram is increased [56,95]. An increase in winter precipitation during El Niño was also found for Northwestern India, with greater moisture flux from the Caspian and Arabian Seas [96]. Conversely during La Niña a strong monsoon reduces the influence of the westerlies over the Karakoram. Through Empirical Orthogonal Function (EOF) analysis, it was demonstrated that the leading EOF of observed precipitation variability contained $63.4 \%$ of the variance and was significantly correlated with the Southern Oscillation Index [79].

\subsubsection{Pacific Decadal Oscillation and Indian Ocean Dipole}

Another teleconnection pattern with influence over the Karakoram is the Pacific Decadal Oscillation (PDO). The PDO represents a combination of processes operating on different time scales and is driven by remote tropical forcing and North Pacific atmosphere-ocean interactions [97,98]. The teleconnection pattern associated with the PDO is similar to that of ENSO, only weaker in amplitude. It therefore modulates the effects of ENSO on the monsoon such that the positive phase of PDO increases the influence of El Niño on the Indian Summer monsoon $[95,99]$. Thus when an El Niño event coincides with a positive PDO, there is a much weaker Indian Summer monsoon than what is expected by the effects of El Niño alone. It was also demonstrated through a comparison between the leading EOF of observed precipitation variability and the $200 \mathrm{hPa}$ geopotential height that there is a significant connection between spring precipitation in Pakistan and the Pacific-North American (PNA) teleconnection pattern associated with the PDO [79].

The equatorial Indian Ocean has a direct influence on the Indian summer monsoon and, like the Pacific Ocean, it exhibits interannual variability in the form of the Indian Ocean Dipole (IOD) which, like ENSO, is characterized by sea surface temperature anomalies. A composite index of ENSO and the IOD shows a significant relationship between Indian Summer monsoon precipitation extremes and this composite index suggesting that, when the two teleconnections are in phase, the extremity of the Indian Summer monsoon precipitation anomalies is enhanced [100]. A similar conclusion was reached through a Bayesian dynamic modeling approach that determined the phases of ENSO and of the IOD have similar effects on Indian Summer monsoon precipitation [101].

\subsection{Climate Change and Trends}

Precipitation trends can be analyzed using weather station data, although existing stations are located at much lower elevations than the glaciers. Archer and Fowler [49] analyzed the precipitation record of 17 stations in the Upper Indus Basin, which range from the Karakoram to the Hindu Kush 
Mountain Ranges. Station altitudes ranged between $980 \mathrm{~m}$ to $2394 \mathrm{~m}$, and the time period ranged from 1895 to 1999. The authors found no significant trend in either annual or seasonal precipitation for the entire period; however, there was a positive trend in winter and summer precipitation for the period from 1961 to 1999.

Temperature trends for the same period using weather station data showed a significant increase in winter mean and maximum temperature [50]. The mean and minimum summer temperature, on the other hand, both exhibited a significant decrease. The authors suggest the observed increase in summer precipitation as a possible explanation for the decrease in summer mean temperature. The decrease in summer minimum temperature could be explained if there were a decrease in cloud cover during the night as this would allow more radiation to escape to space, but there is no data to support such an explanation.

The observed increase in winter and summer precipitation and decrease in summer temperature could explain the advance of glaciers in the Karakoram, as opposed to the glaciers in the central and eastern Himalaya. The increase in winter temperature is not important for the ablation of glaciers, as winter temperatures are sufficiently below zero, and a modest increase would not raise the temperature above the freezing point. The decrease in summer mean temperature is important because it occurs during the ablation season.

Not all glaciers in the Karakoram are advancing and surging, however, and further investigation is required to determine the dominant factors governing this glacier state. As the relief over the Karakoram Himalayas is extreme, multiscale topographic effects governing surface irradiance is expected to partially reduce ablation [102], however, it can also cause strong orographic effects throughout the region.

\subsection{Regional Climate Models}

The fate of glaciers in the Karakoram is linked to a number of factors including climate and topography. To address the climatic aspect of this, numerical modeling of regional climate over the Karakoram has been performed, using data from global general circulation models as the driving boundary conditions. A surface energy balance atmosphere-glacier model has been developed that improves the surface energy balance characteristics over debris-free glaciers of the Karakoram [103], and this model has been extended to include the impact of debris cover on atmosphere-glacier dynamics, with specific application to the Baltoro glacier $[57,58]$.

Regional numerical models have also been used to make predictions of climatic conditions of the Karakoram over the next century, with estimates of glacier response derived from surface energy balance considerations [81]. However, even the highest resolution regional models $(2 \mathrm{~km})$ are still unable to capture the detailed topography of the Karakoram. An assessment of the impact of climate change that includes sufficiently detailed topographic representation and orographic precipitation has yet to be done. In addition, a synthesis of all glacier and climate-glacier modeling efforts over High Mountain Asia has yet to be performed following the example of Fernández and Mark who reviewed the glaciological research over the Andes Cordillera [104].

\subsection{Climate and Topography}

The Karakoram Himalaya exhibits complex climate-glacier dynamics that operate within a mountain geodynamics framework $[27,56,105]$. High-magnitude erosion and uplift governed by climate forcing is responsible for relief production and extreme topographic anisotropy that is also governed by lithological variations. Collectively, such complex topographic variation regulates precipitation rates, orographic precipitation gradients, shortwave and longwave irradiance fluxes, glacier debris-load depth, and highly variable glacier states and dynamics $[27,33,66,106]$. Consequently, precipitation forcing is responsible for positive glacier mass-balance conditions and advancing glaciers [30,59], although the issue of mass loading as a contributing factor to the surging mechanism is not known with certainty [107]. 
It is widely recognized that we lack adequate climate data from high altitudes to characterize precipitation partitioning, orographic precipitation, snow accumulation rates, as well as individual glacier mass loading estimates. In addition, surface irradiance variations at high altitudes are not widely available to characterize the temporal variations of the shortwave and longwave fluxes that are a function of location and multi-scale topographic effects. Furthermore, we do not know to what degree glaciers are responding to internal and/or external forcing factors. The scientific community, however, recognizes that climate, topography, and supraglacial debris cover are fundamental factors that must be better understood $[27,46,53,59]$. Nevertheless, the topography governs the magnitude of surface processes that regulates ablation, debris-cover depth, debris-cover mineralogy, sediment fluxes, glacier erosion, rock strength, relief production, and tectonic deformation and uplift; all of which feedback on and govern glacier dynamics at a variety of spatio-temporal scales.

With respect to climate systems, both the monsoon and the Westerlies are depositing orographic precipitation based on their trajectory and also based on the topography along their path. Unfortunately, the spatial heterogeneity of precipitation in the Karakoram is not adequately characterized and depicted by climate reanalysis products or most regional-scale climate simulations [108]. Furthermore, such annual precipitation patterns do not spatially coincide and thereby explain glacier size or mass distributions due to climate-topographic forcing and highly variably orographic precipitation distributions with time. Future snow accumulation and ice and sediment fluxes in the Karakoram will be severely impacted by increasing amounts of atmospheric greenhouse gases, global temperatures, and varying wind circulation and velocity patterns (governed by changing regional atmospheric dynamics and teleconnections). However, competing and interacting climate and geomorphological effects make it unclear the degree to which precipitation and/or radiative forcing will govern the sensitivity of glaciers to climate forcing in the Karakoram.

Addressing the issue of orographic precipitation and glacier-mass loading will be an important research direction. The spatial and temporal variations in wind direction and velocity, given the intersection of the westerlies and the monsoon, need to be accounted for in relation to the complex anisotropic terrain structure that includes local and meso-scale topographic effects governing the surface irradiance and precipitation (i.e., cast shadows, hemispherical topographic shielding, local slope and slope azimuth angle, relief, and adjacent terrain conditions). Atmospheric moisture fluxes must also be considered. Consequently, regional-scale climate simulations $(<5 \mathrm{~km}$ resolution) provide a detailed methodology with which to address these issues. However, there are limits with respect to the utility of parameterization schemes at high resolution, as well as the need to account for greater topographic complexity.

Downscaling of climate parameters and synthesis with high-resolution topographic information is required. For example, the relationship between wind-flow direction and the terrain geometry is necessary to identify hill slopes exposed to the wind exhibiting the potential for orographic uplift and precipitation. In this way, the wind direction and strength, coupled with local and meso-scale topographic properties can be used to highlight and predict orographic precipitation zones.

We demonstrate this in Figure 3 by combining information from ERA-Interim climate data with the Shuttle Radar Topographic Mapping Mission (SRTM) to identify terrain exposed to the wind. The highlighted terrain conforms to the wind-source direction and depicts orographic precipitation zones. We expect that the orographic precipitation distribution over the Karakoram would exhibit less spatial coverage, compared to wind-exposure patterns, if we accounted for moisture mass loss. Nevertheless, it is clear that many glaciers in the Karakoram exhibit an altitudinal gradient and slope orientation that can potentially cause orographic precipitation to occur directly over a glacier surface. Such is the case in Figure 3 that depicts the result of potential orographic precipitation from the westerlies and the monsoon. 


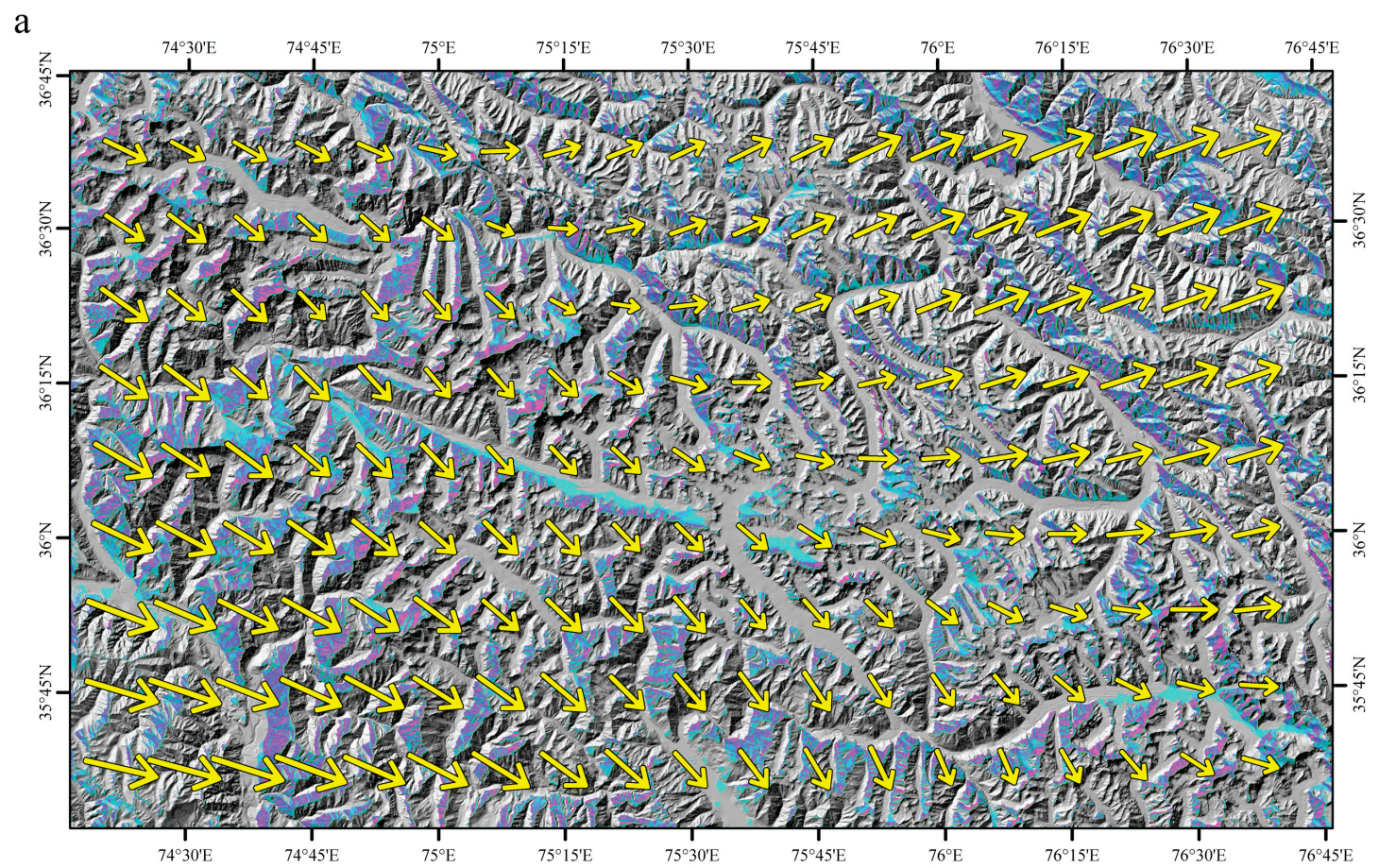

$\mathrm{b}$

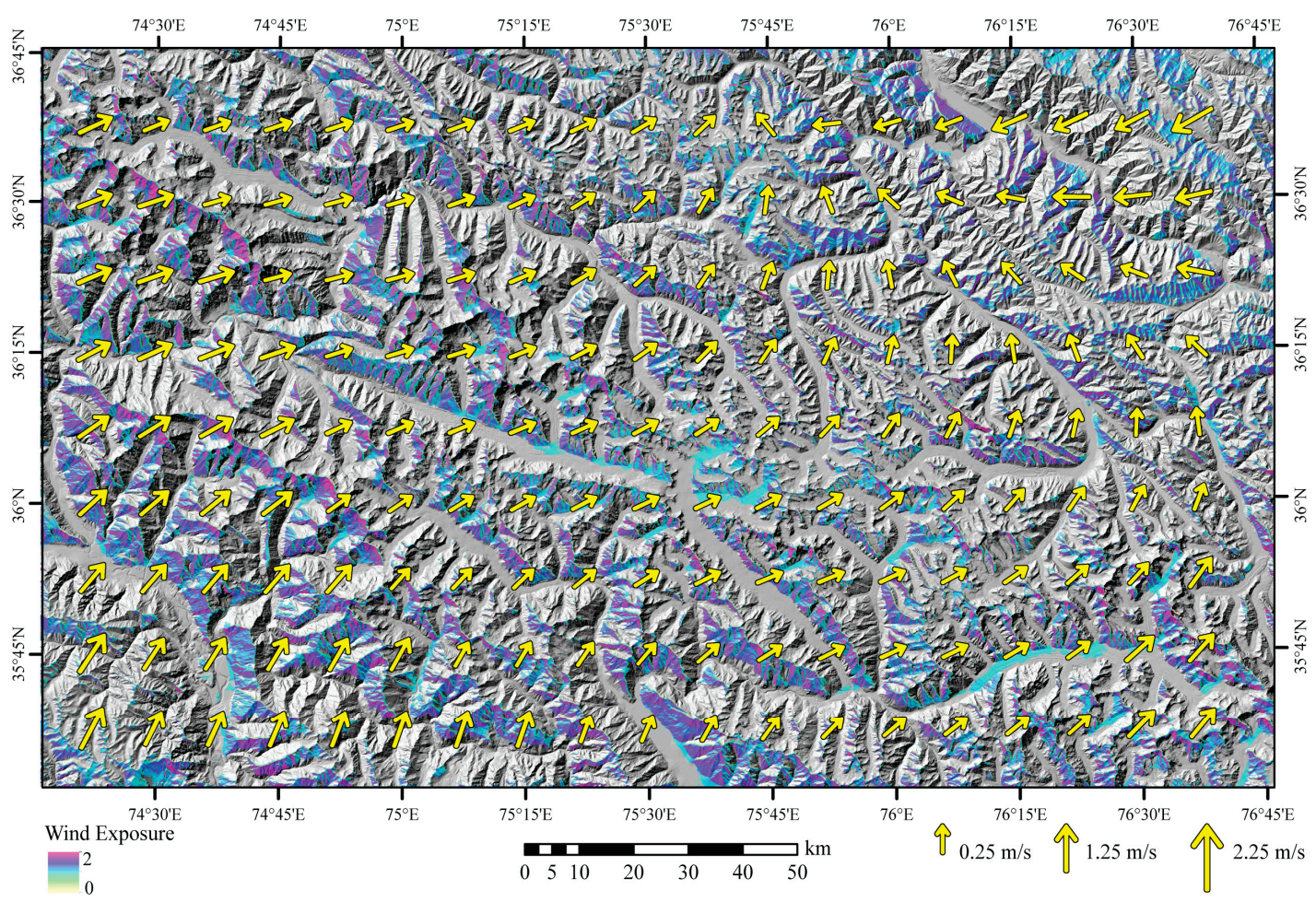

Figure 3. Terrain windward exposure (a unitless index) of the Westerlies in the Central Karakoram in: March (a); and August 2013 (b). Demonstrated are variable wind directions across the Karakoram coupled with the anisotropic nature of the topography generating variability in orographic precipitation patterns.

For moderate-to-smaller glacier basins in the Batura Mustagh and Shimshal Valley regions, terrain wind-exposure zones are highly correlated with basin and glacier size, with the location of large tributary glaciers, as well as with glacier erosion histories that have produced significant meso-scale basin relief. Furthermore, it is plausible that temporal orographic mass loading variation explains 
variations in glacier velocity profiles from year to year. Increases in annual precipitation have been clearly shown to be associated with increases in the magnitude of glacier ice-flow velocity profiles [109]. It will also be important to determine whether surge-type glaciers exhibit more mass loading compared to non-surging glaciers. This basic type of information synthesis and climate downscaling represents an important research opportunity that may provide insight into the role that topographic properties have on climate forcing that ultimately governs glacier dynamics.

Multi-scale topographic effects also govern surface irradiance and ablation dynamics. The shortwave irradiance flux dominates the magnitude of the surface energy balance [102], although the spatial variations in surface irradiance vary significantly over the ablation season. Topographically controlled direct irradiance exhibits distinctive irradiance patterns over glaciers (Figure 4). Surface irradiance simulations that characterize complex multi-scale topographic effects have indicated that many advancing glaciers and surge-type glaciers receive less daily direct irradiance than retreating glaciers at various times over the ablation season. The impact of meso-scale topography on irradiance variations on glaciers over the ablation season needs to be more rigorously characterized.

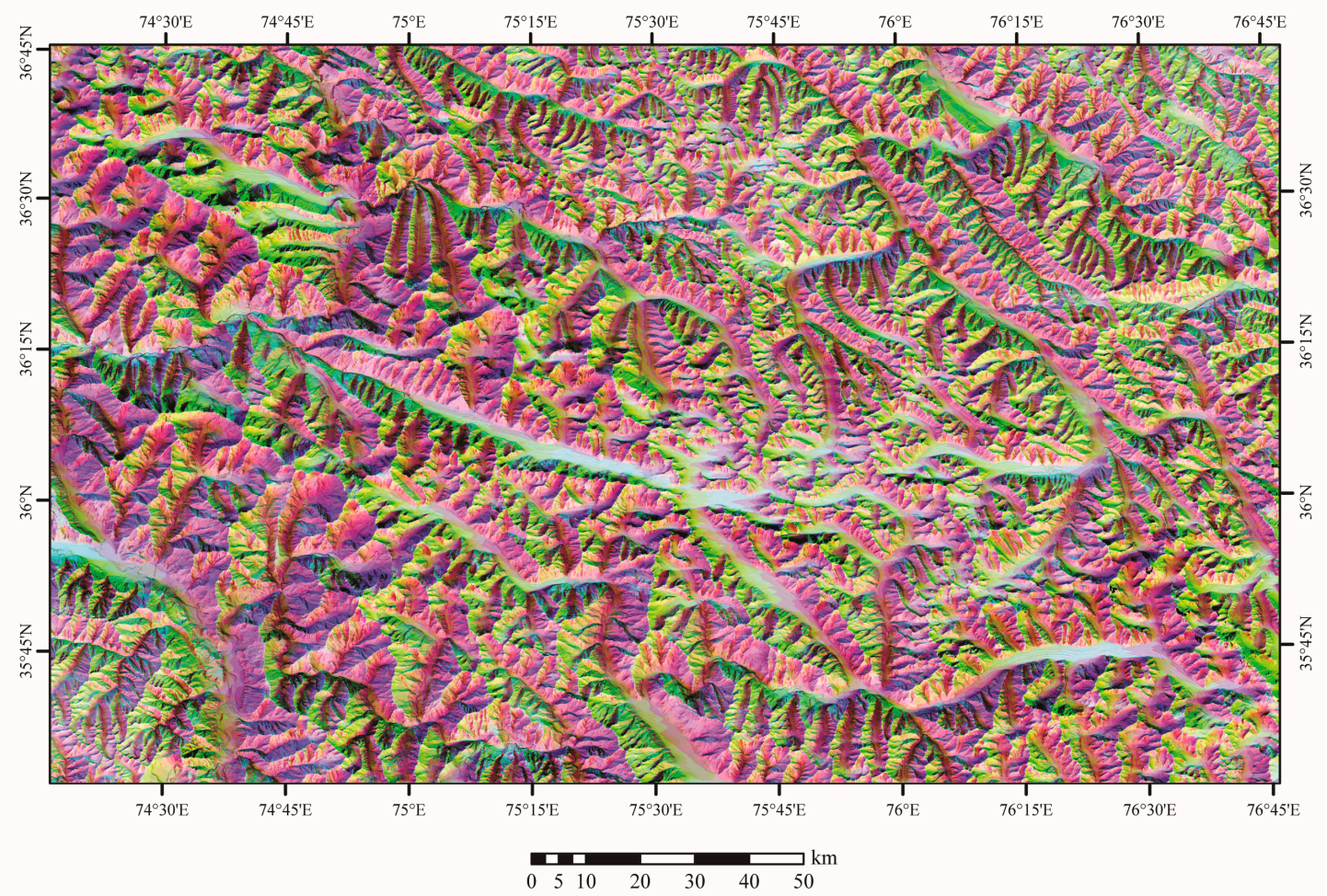

Figure 4. False-color composite image of information generated from a diurnal simulation of direct irradiance on 15 August 2013 over the Central Karakoram using the Spectral Topographic Solar Radiation Model (STSRM) version 1 developed by the authors [110]. Total diurnal energy is depicted by red, while the degree of morning shadowing is depicted by green, and the degree of evening shadowing depicted by blue. Light-tone colors signify more irradiance and less topographic effects, while darker colors depict less surface irradiance and more topographic shielding.

\section{Glaciers}

\subsection{Glacier Fluctuations and Trends}

\subsubsection{Worldwide}

Worldwide, glaciers have been retreating with a typical rate of midlatitude mountain and valley glaciers of 5-20 mear $^{-1}$ [111], and at an estimated global glaciers mass loss of $-259 \pm 28$ gigatons 
per year for the period 2003-2009 [23]. The mass balance of glaciers and ice caps worldwide (excluding Antarctic and Greenland glaciers) was estimated as slightly below zero in 1970; however, it is estimated to be growing more negative since then [16]. The mass balance of Asia High Mountain glaciers is decreasing less rapidly than the mass balance of Alaskan and Arctic glaciers but more rapidly than the mass balance of European, Andean, and US and Southwest Canadian glaciers. In this context, the Karakoram Anomaly stands out and demands an urgent need to characterize processes and forcing factors that can be used to explain and understand complex glacier geodynamics in the region.

\subsubsection{Himalaya}

The literature on Himalayan glacier mass balance change is actively growing. Often, inference of the whole region is based on selected glaciers. Ten glaciers around Mount Everest were selected, and mass balance change through differencing of digital elevation models (DEMs) was performed, using declassified Corona stereo images from 1962 and 1970, aerial photographs from 1984, and Cartosat-1 stereo images from 2007 [39]. The study determined that all ten glaciers lost mass for the period, with the specific mass balance change between 1970 and 2007 calculated as $-0.31 \pm 0.08 \mathrm{~m}$ w.e. year $^{-1}$ (w.e.: water equivalent). It was also established that mass loss occurred in debris-covered areas of the glaciers. Additionally, three benchmark glaciers in the Nepalese Himalaya that had been observed since the 1970s were selected, and GPS surveys were performed on their surface between 2008 and 2010 [112]. The surveyed glaciers have been losing mass for the whole period, but two of the glaciers are located in humid environments and have been losing mass more rapidly. This confirms that glaciers in humid environments may be responding more rapidly to atmospheric warming due to their extension into lower altitudes. The ice at lower altitudes is maintained because of more frequent snowfall that maintains and protects the ice through the ablation season [112].

\subsubsection{Karakoram Himalaya and Karakoram Anomaly}

A regional-scale study was also performed across Eastern and Western Himalaya, the Karakoram, and Pamir [28,29]. A Shuttle Radar Topography Mission (SRTM) DEM from February 2000 was compared to DEMs from SPOT5 stereo images from 2008 to 2011. It was found that glaciers in the Eastern and Western Himalaya have negative mass balance, while some of those in the Karakoram and Pamir have positive mass balance. The total mass balance of the glaciers in the Pamir-Himalaya-Karakoram region is still negative, however, at $-0.14 \pm 0.08 \mathrm{~m}_{\text {year }}{ }^{-1}$. It should always be considered that the accuracy and uncertainty of mass balance estimates derived from differencing of DEMs are related to the accuracy of these elevation datasets [113], and pre-processing of DEMS to reduce error is essential [114].

Another regional-scale study of glacier thickness changes was also performed utilizing Ice, Cloud, and land Elevation Satellite (ICESat) altimetry data for 2003-2008 and the SRTM DEM [31,115]. The large spatial footprint of ICESat defines the resolution of the study area, but it also allows for a comprehensive study of Himalayan mass balance change. The study confirmed the Karakoram Anomaly, but it also determined that the Karakoram is at the Western limit of the region where glaciers are gaining mass with the largest mass gain present at the Eastern Nyainqêntanglha. Kääb et al. [31] estimated $21,000 \mathrm{~km}^{2}$ of glacierized area in the Karakoram and a net mass balance of $-0.10 \pm 0.06 \mathrm{~m}$ year ${ }^{-1}$.

The documented advancing and thickening of some Karakoram glaciers has been named the Karakoram Anomaly, in contrast to the decline of glaciers in other parts of the world [30]. There are different estimates of the total glaciated area in the Karakoram: 16,600 km², reported by Dyurgerov and Meier [14]; 21,771 km², reported by Arendt et al. [60]; and 21,000 km² reported by Kääb et al. [31]. The historical record of the state of retreat and advance of glaciers since the end of the Little Ice Age is lacking due to limited observations. A review of the observations of the Himalayan and Karakoram glaciers between 1850 and the 1970s is available by Mayewski and Jeschke [116]. Noted is the presence of surging glaciers in the Karakoram, but these were excluded from the analysis, as the authors determined that these glaciers represent only a small portion of the record and that the surges are 
spurious. From the rest of the observations, it was established that the glaciers in the region including the Karakoram were: either retreating or advancing between 1850 and 1880; equally in a state of retreat, advance, and stability between 1880 and 1940; or, in a state of retreat between 1940 and the 1970s [116]. Since the late 1990s, the Karakoram glaciers are reported to have stabilized, and in certain high altitude areas, to advance, while surging glaciers are also reported $[30,61]$. The Karakoram Himalaya also exhibits rock glaciers $[117,118]$, which are not reviewed in this paper.

\subsection{Unique Glacier Characteristics and Climate-Glacier Interaction}

\subsubsection{Type of Accumulation Area}

The type of accumulation area (or nourishment type) of the Karakoram glaciers is another distinctive characteristic contributing to their stability according to Hewitt [61] who utilizes the terms Turkestan-type and Mustagh-type to distinguish the glaciers with that regard. Both Turkestan-type glaciers and Mustagh-type glaciers do not have a typical accumulation area, but are instead snow-and-ice avalanche-fed. The distinction between the two types of glaciers is that ice streams start below the snow line for Turkestan-type glaciers, but the ice streams start above the snow line for Mustagh-type glaciers. There are also some glaciers in the Karakoram that are of Alpine type, which are the typical snow-fed glaciers with extensive accumulation zones. The distinction based on the type of accumulation area is important because avalanche-fed glaciers are less sensitive to changes in the snow line and thus less sensitive to climate change, whereas, with Alpine-type glaciers, small changes in the snow line alter the size of the accumulation and ablation zones. Hence, Turkestan-type glaciers and Mustagh-type glaciers are potentially less sensitive to temperature changes.

\subsubsection{Ablation Variations due to Glacier Surface Features}

In terms of the ablation regime of Himalayan glaciers, it is important to quantify how much of the ablation happens where different glacier features are located. Thus, an estimation of the ablation regime of a glacier may be possible if the spatial distribution of various features is mapped. Given this objective, Juen et al. [119] applied a distributed ablation model to study ablation rates in western China. The authors estimated through image analysis that debris-cover extends over $32 \%$ of the glacier, and that ice cliffs and supraglacial lakes encompass $1.7 \%$ and $0.36 \%$ of the debris-covered area, respectively. The authors found that the ice cliffs account for much less ablation than previously reported-between $7 \%$ and $16 \%$ of the total ablation in the debris-covered area of this glacier, while the ablation over all debris-covered area accounts for between $17 \%$ and $33 \%$ of the total ablation of the glacier. Still, according to Kraaijenbrink et al. [120], the effects of supraglacial lakes and ice cliffs counteract the effects of debris-cover on some glaciers, to the extent that Himalayan debris-covered glaciers may have similar rates of surface height change as debris-free glaciers. Ice cliffs and supraglacial lakes are further discussed below.

\subsubsection{Debris-Cover}

A very important distinguishable characteristic according to Hewitt [61] is the presence of thick debris-cover but only over portions of glacier surfaces (see Figure 1). For example, Bishop et al. [121] utilized remote-sensing image analysis to estimate that $75.3 \%$ of the total area of Batura glacier is covered with debris more than $0.3 \mathrm{~m}$ deep. In certain areas, however, only a thin layer of debris is present, enhancing ablation, while there are also areas of clear ice where ablation is not enhanced. The portions covered with thin layers of debris, or those that are debris-free, are sensitive to summer precipitation as the occurrence of snowfall limits ablation.

The presence of debris-cover on Karakoram glaciers is an important surface property, as it modulates ablation rates. Thin debris-cover enhances ablation rates, whereas thick debris insulates the glacier, decreasing the ablation rate to the point where these glaciers can exist at much lower altitudes than if they were debris-free $[59,122,123]$. Thus, the effects of debris-cover on the thermal properties of 
the Karakoram glaciers is significant and is expected to lead to erroneous mass balance estimates if not accounted for.

Reznichenko et al. [124] studied the effects of debris-cover on glacier ice in a laboratory environment. The insulating effect of thicker debris-cover (greater than $5 \mathrm{~cm}$ ) is only possible when diurnal cycles of radiation forcing are present, as nighttime allows for the absorbed energy to be emitted back to the atmosphere. Another important finding was the impact of the permeability of debris-cover on heat transfer during rain events. In particular, thin and highly porous debris allows rain to advect heat to the glacier surface. However, if the debris is not highly permeable, the rain may freeze within the debris-cover at night and stay frozen during the day, not allowing further rain to reach the glacier surface, thereby decreasing surface ablation.

Rowan et al. [123] coupled ice flow and debris-cover within the iSOSIA numerical model [125], and included mass-balance and debris-accumulation feedback. The model was applied to the Khumbu Glacier, Nepal, revealing that the glacier responded to warming by mass loss and thinning-and not by a decrease in its spatial extent. The debris-cover also slowed the response of the glacier to warming. Even though the Khumbu Glacier is not located in the Karakoram and is in a different climate setting, the results of the study are still transferable, as the glacier is large, heavily debris-covered, and mostly avalanche-fed. This modeling effort focused on the spatial pattern of debris-cover but ignored the temporal evolution of debris production.

In the Karakoram, Mihalcea et al. [62] investigated the effects on glacier ablation through a distributed surface energy-balance study. The study utilized remote-sensing, ASTER, and field data to derive the spatial distribution of debris-cover over the Baltoro Glacier and a meteorological station adjacent to the glacier in order to measure the energy available at that location. This study also highlighted the importance of accounting for debris-cover in the energy regime of the glaciers.

Alternatively, Collier et al. [58] investigated the effects of debris-cover on glacier-atmospheric interactions by introducing surficial debris to the coupled atmosphere-glacier model WRF-CMB [103]. Accounting for debris-cover is essential to the modeling of Karakoram glaciers because excluding debris-cover could lead to an approximately $14 \%$ over-estimation of ice loss. Moreover, the debris-cover also modifies the meteorological fields, especially over the lower portion of the glaciers, as well as the exchanges of sensible and latent heats between the surface and the atmosphere. It should also be noted that there is a feedback between climate and erosion because debris-cover is a function of the erosional processes in the vicinity of a glacier, since mass movement supplies the material that is deposited on the glacier. In addition, debris-cover is also a function of the topography of the terrain because steep accumulation areas are related to the formation of debris-covered glaciers [59]. Due to the feedback between climate and erosion rates, debris-cover is expected to increase in a warming climate. Understanding debris production and its effects on glaciers is essential, and it has been demonstrated by Scherler et al. [59] that similar climate settings result in different glacier behavior in the Himalayas depending on the presence of debris-cover.

Debris-cover is highly variable, both horizontally and vertically, with most of it being present in the ablation area of the Karakoram glaciers, and with thickness generally increasing toward the terminus of the glaciers, reaching a maximum depth greater than $5 \mathrm{~m}$ [56]. Mapping debris-cover and estimating its depth are active research areas in glaciology [62,121,126-131]. An innovative study by Casey and Kääb $[132,133]$ also mapped geochemical composition of debris-cover cover through in-situ and remote sensing spectral analysis.

Some of the early work on debris-cover mapping was performed by Bishop et al. [121], using SPOT images and ISODATA unsupervised classification to derive not only the spatial variability but also the thickness of debris-cover. Mihalcea et al. $[62,130]$ utilized the thermal ASTER bands and mapped the spatial distribution and thickness of debris-cover through a correlation between surface kinetic temperature and debris-cover characteristics. This correlation was applied over the Baltoro glacier even though it was developed over the Miage Glacier, Italy with a stronger correlation of $R=0.8$ over a continuously debris-covered area, as well as a weaker relationship of $R=0.69$ over the whole 
glacier tongue. Khan et al. [129] also mapped different types of land cover common in glacierized basins such as perennial snow-cover, clean ice, and debris-covered ice. This is a semi-automated approach, using Landsat images and terrain slope as inputs to a supervised maximum likelihood classification that segments the study area, which is then completed by manual post-processing. All of these efforts in mapping debris-cover are essential, as we need to be able to better characterize glacier surface energy-balance conditions.

\subsubsection{Ice Cliffs and Supraglacial Lakes}

The presence of ice cliffs and supraglacial lakes are another unique characteristic of glaciers (Figures 5 and 6) as both of these features are associated with high-magnitude ablation, and ice cliffs contribute considerably to the overall ablation of a glacier even though they often cover only a small percentage of the glacier surface [120,134-137]. Theoretically, these features and glacier ablation form a positive feedback loop-an ice cliff exposes clean ice while supraglacial lakes exhibit low albedo both of which increase ablation. The enhanced ablation further contributes to the expansion of ice cliffs and supraglacial lakes. In actuality, ablation rates on ice cliffs vary according to their orientation and inclination, local shielding effects, and the presence of debris-cover as demonstrated on the Lirung and Khumbu Glaciers, Nepal [138].

Ice cliff formation, however, has not been studied sufficiently with only two formation mechanisms described in the literature-ice cliffs can be formed when the roof of an englacial conduit collapses or when a debris-layer slides and exposes clear ice [138-141]. Ice cliffs occur commonly over the lower portions of a glacier due to mass wasting, thinning of the ice, and the eventual collapse of the roof of conduits. When that happens, the resulting feature appears as a funnel-shaped sink hole [141]. Ice cliffs are dynamic and are further modified by ablation and ice flow. Sakai et al. [138] identified four types of ice cliffs during their study of Lirung Glacier, Nepal—decayed, temporary, developed, and stable. When they are first developed, their area increases. When they are stable their area does not change. Decaying ice cliffs lose their surface area. The identified temporary ice cliffs were formed due to debris-layer sliding during the monsoon season, and are covered again with debris in the post-monsoon season.

Ice cliffs vary in shape but also in type due to their different orientation, as orientation represents a strong controlling factor for ice-cliff ablation. On Lirung Glacier, Nepal, ice cliffs facing north to west were larger and were determined to have continuous ice exposure with similar ablation at their lower and upper parts, and thus these ice cliffs maintained their steep slopes [138]. At the same time, ice cliffs facing northeast to south were smaller and appeared shielded at their lower portions exhibiting lower slopes, which also tend to be covered by debris. Sakai et al. [138] explain these differences given variations in shortwave and longwave irradiant fluxes. A more recent object-oriented analysis of glacier features on Langtang Glacier, Nepal also identified north-facing ice cliffs as larger and often accompanied by a supraglacial lake formation [141].

Further insight into ice-cliff dynamics was gained by Buri et al. [135] who developed a grid-based model of cliff backwasting which accounts for the interactions between shortwave and longwave irradiant fluxes, and glacier topography. The model was applied to two ice-cliff features on Lirung Glacier, Nepal, and pre-monsoon, monsoon, and post-monsoon radiation fluxes were computed. In all six scenarios, the diffuse irradiance was the largest shortwave flux when compared to direct or adjacent-terrain irradiance fluxes, with mean diffuse irradiance varying from $48.8 \%$ to $64.8 \%$ of the mean incident shortwave irradiance. In four out of the six scenarios, the mean outgoing longwave radiation flux was larger than the mean incoming longwave radiation flux. However, the amount of the incoming longwave radiation is still important with the sky-longwave irradiance dominating but with considerable mean debris-emitted longwave radiation ranging from $24.2 \%$ to $27 \%$ of the total incident longwave radiation. These estimates confirm the importance of considering the terrain but also the type and relative location of debris-cover when examining the effects of ice cliffs on ablation. 


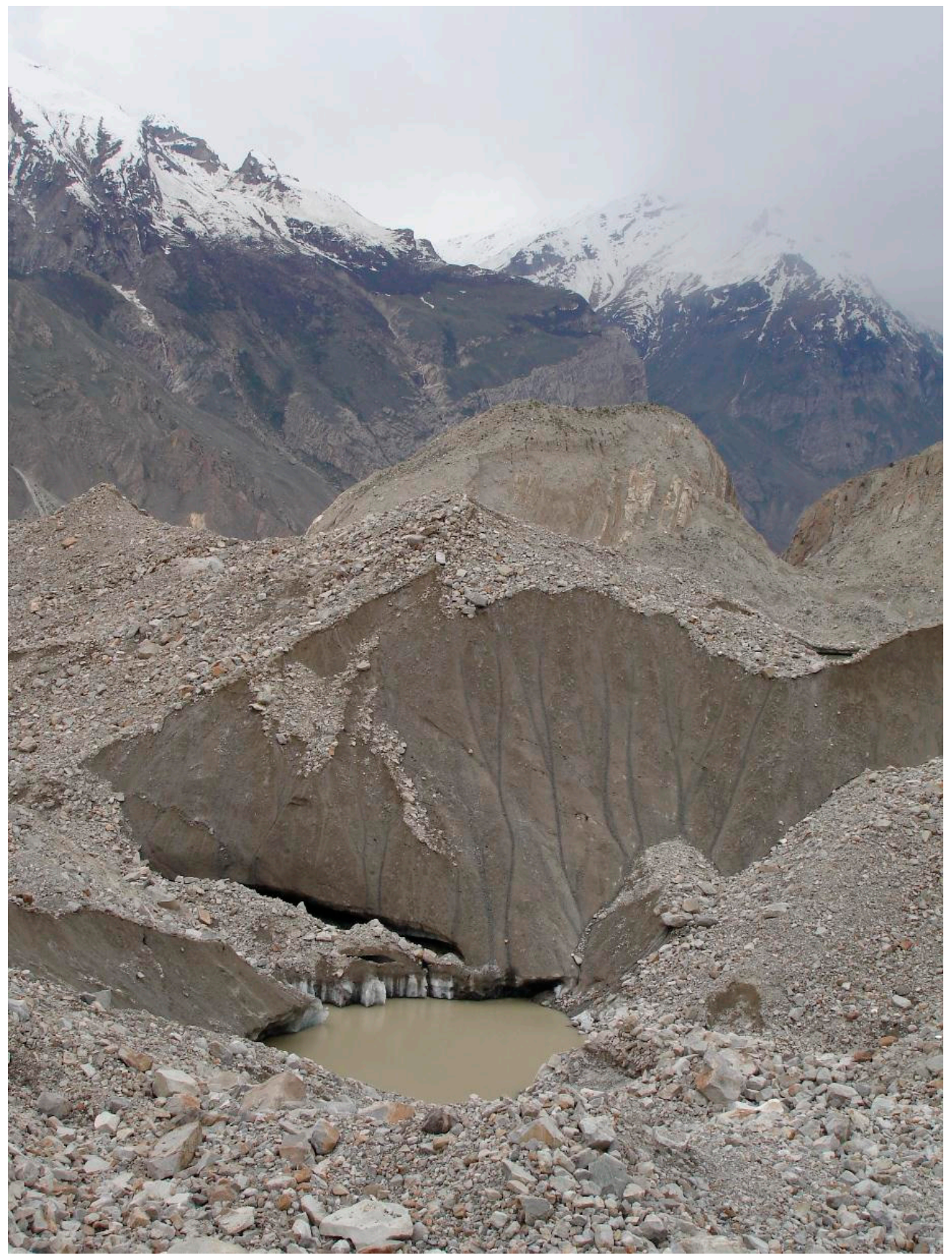

Figure 5. A debris-covered ice cliff and a small supraglacial lake on Baltoro glacier (photo credit: Andrew G.B. Bush, 2005).

Ablation is enhanced due to exposed ice, so often supraglacial lakes are formed at the base of ice cliffs, and Kraaijenbrink et al. [120] demonstrated the prevalence of these coupled systems by mapping them over a lower portion of the Langtang Glacier, Nepal. Supraglacial lake formation is also of extreme interest because such lakes are a hazard for the onset of Glacial Lake Outburst Floods (GLOFs) and large lakes upstream from mountain communities are often monitored [142-144]. Thus, most of the effort in studying glacier lake formation has been focused on moraine-dammed lakes at the terminus of the glaciers which are at risk of GLOFs, and Sakai et al. [145] demonstrated statistically that such lakes form on glaciers where the inclination of the glacier surface is less than $2^{\circ}$ and also where there has been lowering of the glacier surface since the Little Ice Age. 
In terms of supraglacial lakes not at the terminus of the glacier, the general understanding is that they are also due to lowering of the glacier surface. Kraaijenbrink et al. [120] deployed an unmanned aerial vehicle (UAV) over Langtang Glacier, Nepal and found that glacier surface curvature is not related to the presence of supraglacial lakes — the authors identified a decrease in the total extent of supraglacial lakes over a relatively straight stretch of the glacier.

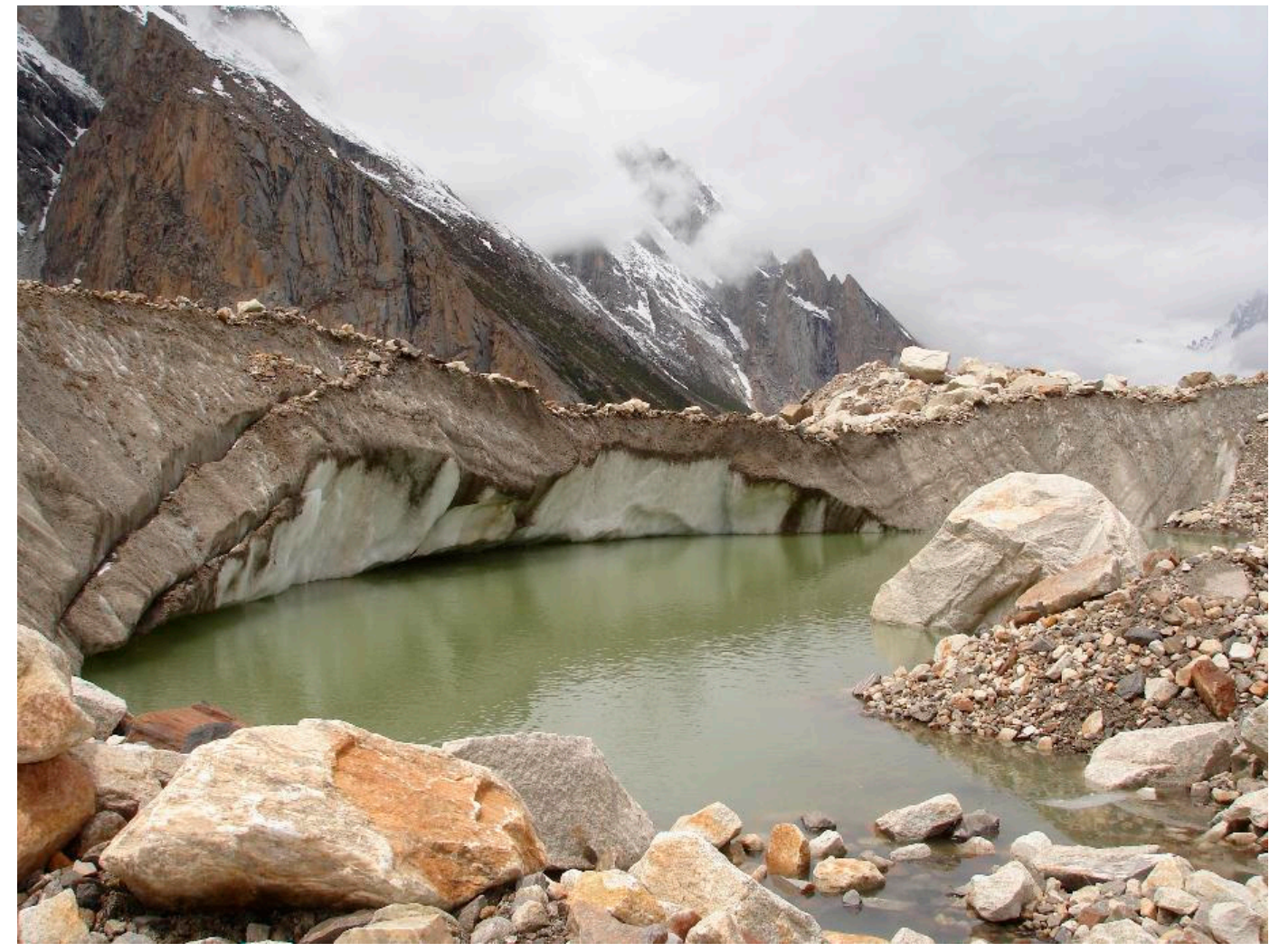

Figure 6. A large supraglacial lake surrounded by ice cliffs on Blatoro glacier (photo credit: Andrew G.B. Bush, 2005).

\subsubsection{Variable Glacier Dynamics and Surging Glaciers}

Essential to our understanding of these glaciers are the highly variable ice dynamics even along portions of even the same glacier $[33,107,146,147]$. Glacier profile estimates of ice velocities provide insight into glacier dynamics and can be used to identify surging glaciers in their active phase of surging. Paul et al. [42] introduced a procedure for deriving glacier velocities developed within the Glaciers Climate Change Initiative (CCI) of the European Space Agency (ESA). Ice velocities currently may be derived through offset tracking of either repeat optical remote sensing images or SAR images [42].

The large number of surging glaciers uniquely define the Karakoram [34,69]. Surging glaciers differ from advancing glaciers in that they undergo long periods of no movement (quiescent phase) and shorter periods of surge [102]. During a surge, a large volume of ice is transferred from the upper portion of the glacier (reservoir area) to the lower portion (receiving area). The velocity of a surging glacier is often 10 to 100 times greater than the velocity of the glacier when quiescent. Furthermore, the velocity is too great to be due to ice deformation alone; therefore, basal slip must be occurring as well [102].

Surge dynamics of Karakoram glaciers were studied by Quincey et al. [148]. The authors identified five glaciers in Pakistan; surface velocities were derived through feature tracking of remote sensing images. Landsat TM and Landsat ETM+ images were used to generate the velocity fields of the three larger glaciers, while finer resolution PALSAR was employed for two smaller glaciers. The authors 
concluded that the surges of these glaciers are thermally and not hydrologically controlled, the evidence for which is the seasonality of surge commencements, as one surge was initiated in the late summer and another in the fall. Additional evidence used to justify thermal control was that the glaciers accelerated gradually after the surge started, with peak velocities being reached about two years later. The quiescent state was reached about two to three years after the peak, with the smaller glaciers advancing considerably. The two smaller glaciers were not heavily debris-covered and are glaciers that were not previously reported to have surged. Large-scale glacier velocity studies such as the one performed by Dehecq et al. [149] will provide further insight into the spatial distribution and character of surging glaciers in the Karakoram Himalaya.

\section{Discussion}

The complexity of climate-glacier dynamics in the Karakoram is the result of numerous feedback mechanisms that involve the coupling of climatic, surface, and tectonic processes. Topographic structure strongly governs radiative and precipitation forcing, and the magnitude of erosional processes further modifies topography. Similarly, erosion dynamics are affected by climate forcing and regulates surface mass loss, governing uplift and topographic deformation. Collectively, these mountain geodynamics operate over a variety of spatio-temporal scales, and explain numerous characteristics about the topography and modern-day glaciers in the Karakoram. For example, paleo-climatic conditions and radiative forcing promoted positive mass balance conditions in the Holocene [66] that would have resulted in large ice depths and driving stresses promoting rapid erosion and relief production, as glacier erosion is thought to scale with ice depth and ice-flow velocity $[150,151]$. High-altitude glacier erosion surfaces are found throughout the Karakoram, representing extensive glaciation [55,152-154]. These conditions and the subsequent retreat of glaciers would have significantly modified the topography and established the current anisotropic nature of the topography that now partially regulates precipitation forcing and glacier surface ablation. Furthermore, we know, based upon our fieldwork and geomorphometric analysis of the topography in the Karakoram [154,155], that many glaciers are differentially influenced by tectonics, such that glaciers in tectonic zones exhibit unique geometries and ice-flow velocities due to flow restrictions and steep slopes caused by glacier erosion and uplift.

Complex mountain geodynamics are also responsible for the size distributions of glaciers and the basins in which they are found. Those glaciers that appear to be receiving more snow accumulation exist in larger basins, and these basins exhibit a relatively low hypsometric integral (i.e., more rock mass removed by glacier erosion). Furthermore, the meso-scale topographic stresses and regional tectonic stress fields govern rock resistance to erosion [153,156], which in turn controls mass movement processes that generate debris supply to glacier surfaces. Lithological and topographic variations, coupled with frequent snow avalanching, explain the heavily debris-covered glaciers in the Karakoram. Therefore, climate, erosion, and uplift dynamics are primarily responsible for glaciation, glacierization, and various aspects of climate-glacier dynamics.

It is this highly coupled geodynamics framework that complicates our understanding of climate-glacier dynamics and glacier sensitivity to climate change. Traditionally, climate and glaciological research has focused on utilizing annual climatic precipitation and temperature regimes to explain glacier states and changes. Temporal climate trends have been used to explain glacier fluctuations and mass balance conditions (e.g., [157]), although such relationships do not adequately account for topographic anisotropy and surface irradiance, supraglacial debris cover properties (e.g., depth, lithology, sediment fluxes), orographic precipitation variations at high altitude, and local convective boundary layer motion and precipitation. These parameters can significantly vary over space and time. Therefore, given observed decreases in summer temperature, we should not expect that glaciers in the Karakoram to retreat uniformly or that the largest glaciers be present where annual precipitation is greatest. An examination of annual precipitation patterns over the Karakoram does not explain glacier size distributions and glacier geometry patterns, nor differentiates "normal" alpine-type versus surge-type glacier distributions 
in the Karakoram, although we do note reduced relief and a different topographic structure in the northwestern portion of the Karakoram over China, where annual precipitation is relatively low, compared to other regions in the Karakoram.

Given such complex geodynamics, there is an urgent need to better understand the Karakoram Anomaly [30-32]. To do so, we must account for a variety of controlling factors, such as climate-system interactions between the monsoon and the westerlies, climatic teleconnections (such as those produced by ENSO), the anisotropic nature of topography, and debris-load dynamics that modulate the influence of climatic variables. Nevertheless, we should expect that the high degree of spatial and temporal variability in glacier fluctuations is the result of orographic mass-loading variability resulting from changing climate-system interactions, as precipitation forcing is thought to most likely be the dominant controlling factor responsible for the spatial anomaly of advancing and surging glaciers, as well as positive mass balance conditions [49,50]. However, we need to know to what degree ENSO influences the monsoon and its penetration into the Karakoram and to what degree does it influence the westerlies in terms of moisture, wind-strength, wind-direction, and orographic precipitation. Given wind-direction variability and wind-strength, we would expect orographic precipitation to be extremely variable over the course of a year. Similarly, how do lithologic variations and topographic structure and stresses control basin rock-fall retreat rates, sediment fluxes, and glacier surface debris accumulation?

Studying such topography-climate forcings should provide new understandings of glacier fluctuations and glacier sensitivity to climate change. Terrain exposure to changing circulation patterns (given variable moisture fluxes) should highlight orographic precipitation zones that could more formally explain glacier-size and glacier-distribution variations across the Karakoram. In addition, climate simulations suggest that the Karakoram Anomaly is the result of the increasing influence of the westerlies caused by El Niño events that cause a weakening of the monsoon, which in turn creates significant spatial variations in orographic precipitation to partially regulate glacier mass balance and terminus-state conditions [158,159]. Furthermore, simulations also suggest that debris mass loading (due to debris-cover accumulation and snow avalanching and basin rock-wall retreat) will influence atmospheric boundary layer conditions, such that, in the future, increases in temperature and debris-cover will increase surface debris temperatures that will cause increased convective motion over glaciers, increasing local precipitation and thereby enhance ablation if the moisture can infiltrate to the ice surface at depth [58]. Therefore, positive mass balance conditions may transition to negative mass balance for these glaciers. These complex atmospheric-topographic-debris feedback mechanisms will need to be investigated to ascertain the timing of climatic mass-balance variations.

Given contemporary conditions, it may be that advancing glaciers exhibit relatively large orographic precipitation zones at high altitude, or in their accumulation area, or in high-altitude/accumulation areas of tributary glaciers. They may also exhibit reduced ablation in topographic zones that generate cast shadows and exhibit relatively strong hemispherical topographic shielding caused by high magnitude glacial and fluvial incision over time (Figure 4). These multi-scale topographic effects reduce shortwave surface irradiance and longwave atmospheric irradiance over glaciers. Such topographic influences over the ablation season have yet to be formally quantified.

It is not yet necessarily clear that retreating glaciers exhibit less mass loading in their accumulation area, as relatively high ablation rates could be responsible for retreating termini and downwasting. Furthermore, increased ablation due to the presence of ice cliffs and supraglacial lakes may accelerate ablation and downwasting over segments of glacier surfaces [84], although termini debris load and ice-discharge conditions could promote relatively stable termini positions. Finally, it is also necessary to understand the nature of atmospheric temperature change and the influence of clouds on the longwave irradiance that also governs ablation dynamics. Steiner and Pellicciotti [160] found that diurnal variations in air temperature can vary significantly in mountain environments. Consequently, feedback between energy balance, ablation, sediment fluxes, topography, and ice-flow dynamics regulates glacier geometry, termini variations, and glacier-surface morphometric structure. 
These complex geodynamics also govern surge-type glaciers in the Karakoram $[107,146]$. Surging glaciers exhibit quasi-periodic advances or increases in flow that are thought to be unrelated to external factors [161]. In the Karakoram, they exhibit relatively high flow velocities, ranging from 250 to $2000 \mathrm{~m}$ year $^{-1}$ [33]. Surge mechanisms are thought to be thermal and hydrological in nature, although Copland et al. [155] have indicated that multitemporal ice-flow velocity profile patterns support the possibility of mass loading as a controlling factor. Furthermore, it has been stated that the large number of surging glaciers in the region suggests a correlation between climate and surge-type glacier locations. Sevestre and Benn [52] found a first-order climatic envelop, where both nonsurge-type and surge-type glaciers can coexist. Their data on mean annual temperature and precipitation could delineate surging clusters that confirm that climate is a primary control on the distribution of surge-type glaciers.

Numerous statistical and field studies have been conducted to identify controls on surging behavior (e.g., [162-166]). It has been suggested that topographic and geological controls may be significant [33,155]; however, formalization of multi-scale topographic effects on processes such as debris production, ablation, melt water production, and glacier surface morphometric and geometric factors have yet to be adequately investigated. Tectonics and lithological controls, glacier geometric complexity, and tributary ice-discharge locations, in relation to mass loading and melt water production, may also explain surging and ice-flow distribution patterns.

Given that glacier dynamics are governed by mountain geodynamics, it is reasonable to assume that glacier surging behavior may be different for glaciers in separate basins and that there may not be a single surging mechanism operating in the Karakoram. Quincey [33] reached the same conclusion and found that different styles of surges can be accounted for by examining individual glacier configurations that are ultimately defined by climate, topography and geological conditions. In the Shimshal Valley, we note that surging glaciers: (1) are relatively long and large; (2) found in tectonic zones; (3) can exhibit relatively large tributary glaciers; (4) exhibit relatively large mass-loading zones at altitude or in the accumulation area (based upon wind-circulation patterns and terrain wind exposure); and (5) have relatively steep altitude gradients. All these characteristics are strongly controlled by the topography and climate. Consequently, more detailed analysis of climate-topography forcing, debris-cover conditions, and localized geological conditions needs to be evaluated [57,58].

Another critical issue for understanding the nature of glaciers in the Karakoram is that of glacier sensitivity to climate change. This topic has been discussed in the literature, however, not from a mountain geodynamics perspective. In general, our understanding has been highlighted in terms of Karakoram glaciers being less sensitive to climate change, given that debris-covered glaciers are insulated by thick debris cover, and surge-type glacier mechanisms are not thought to be caused by external forcing factors [161,167]. The issue is further complicated by semantics, in terms of defining glacier change, and accounting for the concept of glacier response times.

Thick, debris-covered glaciers are thought to be insensitive to increases in temperature because of relatively large debris depths. However, such conditions could cause convection, and localized precipitation could increase ablation as the water makes its way through the debris layer. Furthermore, debris depths are highly variable in the Karakoram, and are controlled by gravity and the topography, melt-water production, suprafluvial erosion and transport of sediment, and ice-flow velocity compression in the terminus region of the glacier. This generalized perspective accounts for glacier deformation and response time theory $[102,168]$ and changes in the cumulative mass balance variation of an individual glacier. The conventional understanding is that larger glaciers respond to climate over longer time intervals, while smaller glaciers respond to climate change over shorter time scales [169]. Nevertheless, research has demonstrated significant changes over relatively short time scales in: (1) glacier geometry and state across all altitudes [27]; (2) glacier hydrology [144]; (3) supraglacial lakes [95]; (4) ice cliffs [138]; (5) ablation dynamics [130]; and (6) ice-flow velocities [146] for glaciers of varying size. Numerous glaciers in the Karakoram are clearly responding to increased mass loading and/or melt water production, as they exhibit annual increases in ice-flow velocities due to driving stresses and/or increased basal water pressures [33]. Furthermore, we saw during our fieldwork on 
Baltoro glacier in July 2005 that glacier surface topography rapidly changes within a week, due to variations in the ablation dynamics caused by sediment fluxes, supraglacial fluvial processes, and the evolution of supraglacial lakes and ice cliffs known to represent high-ablation conditions.

Given these interacting dynamics that operate at multiple scales, one can easily argue that Karakoram glaciers may be highly sensitive to climate-topography forcing and that the rapidly changing process dynamics significantly alters glacier surface and englacial structure. Such complex sensitivity and dynamics may be considered to be strongly nonlinear in nature, and does not have to significantly alter glacier geometry. Furthermore, we lack adequate data to reasonably characterize whether such glacier changes significantly alter mass-balance conditions, as most cumulative ablation and snow accumulation estimates exhibit a high degree of uncertainty. Consequently, rapid downwasting, changes in topographic structure and ablation dynamics, as well as glacier hydrological responses (such as outburst flooding, englacial conduit collapses and glaciofluvial water discharge variations) may reveal significant glacier sensitivity to climate change, as complex feedback mechanisms are generating detectable and measureable changes in glacier dynamics and surface morphological conditions. Glaciers in the region are surging, advancing, retreating, and downwasting, as well as exhibiting lateral outburst flooding, and the nature of oscillations and transition states may be considered a response to mountain system geodynamics, as many glaciers adjacent to each other respond differently $[27,33,69]$.

It is plausible that the debris-covered glaciers in the Karakoram are much more sensitive and susceptible to climate change than previously discussed in the literature. This implies that they may be more dynamic because they respond to high-magnitude process rates that are highly spatio-temporal scale dependent, compared to other areas in the Himalaya, as the Karakoram exhibits complex geodynamics and glaciers responding to both radiative and precipitation forcing. Such complexity may be due to the extreme anisotropic topographic conditions, in which high-magnitude erosion-uplift dynamics and relief production are spatially coincident with two interacting climate systems, resulting in relatively high orographic mass-loading, that drives gravitational stresses to explain the high flow velocities of the region and highly variable glacier fluctuation rates [27]. Precipitation forcing is counter-balanced by radiative forcing, as the past individual glacier erosion history governs the relief and topographic shielding that alters irradiant fluxes. Increased ablation at intermediate and high altitudes can generate altitudinal zones of downwasting that alter driving stresses and glacier-surface topography. We see this occurring over the larger glaciers including the Batura, Hispar, and Baltoro. Furthermore, high-altitude melt water production due to thin layers of debris, steep slopes, and increased driving stresses (gravitational, tributary ice discharge, and mass loading induced) may cause potential glacier dynamic instabilities, explaining the large number of surging glaciers in the region.

The collective nature of all these climate-glacier dynamics, and the nature of glacier variability within the region suggests that Karakoram glaciers are highly sensitivity to local and regional climate, topography and geological conditions. More research into topographic anisotropy and its role in climate forcing is warranted. Finally, the nature and degree of glacier surface topographic change may be an important indicator of glacier sensitivity to climate and geological conditions, as the glacier topography represents the synthesis of competing processes and internal dynamics that is ultimately controlled by climate forcing.

\section{Conclusions}

Over the past several decades, a significant body of research has attempted to characterize the climate-glacier dynamics in the Karakoram Himalaya. Satellite observations and geodetic estimates of mass-changes have revealed relatively stable mass-balance conditions in the Hunza region before 2000 [170], and slight mass-gains after 2000 [31]. A number of researchers report highly variable glacier fluctuation rates, with glaciers in adjacent basins not following regional climate trends. Furthermore, the region exhibits a relatively large population of surging glaciers that, in some local instances, appear to follow similar temporal surging patterns. They have also been found to exist within a 
climatic envelope, suggesting that climate is a primary controlling factor that may play a role in initiating surging.

Research has also highlighted the uncertainty in estimating glacier fluctuation rates and mass-balance, given the utility of different geospatial data sets and methodological procedures. Understanding of the region has been traditionally based upon remote sensing investigations and employing statistical climate trends. Increasingly, scientists are making use of climate simulations and climate-glacier models to investigate complex climate-glacier dynamics. However, we are now beginning to understand that mountain geodynamics also govern the complexities of climate-glacier dynamics, and that the glaciers in the Karakoram are responding to complex interactions involving climatic, surface, and geologic processes. Anisotropic topographic variation significantly governs a multitude of processes, including radiative and precipitation forcing. It also governs debris load availability and therefore various aspects of climate and ablation dynamics.

This review of recent research and the issues that have been discussed provide a foundation for new research directions that better account for the complexities of mountain geodynamics and the scale dependencies of processes that govern glacier responses to climate change. They include investigating:

- Climate system interactions and teleconnections

- Topography-climate forcing and orographic precipitation patterns

- Spatio-temporal surface irradiance patterns and surface energy budgets

- Supraglacial debris load fluxes, depths and ablation distributions

- Ice cliff and supraglacial lake system evolution

- Glacial geomorphological responses to climate change.

Acknowledgments: Andrew B. G. Bush acknowledges funding from the Natural Sciences and Engineering Council, Canada. Michael P. Bishop acknowledges funding from the National Science Foundation. We acknowledge Randy Beeler for language editing and proofreading.

Author Contributions: I.D.D. wrote the climate and glacier sections, and edited the manuscript. M.P.B. wrote the Climate-Topography and Discussion sections, and edited the manuscript. A.B.G.B. edited and helped to write the manuscript, and provided past research as references. All authors contributed to writing the introduction of the manuscript.

Conflicts of Interest: The authors declare no conflict of interest.

\section{References}

1. Akhtar, M.; Ahmad, N.; Booij, M.J. The impact of climate change on the water resources of HindukushKarakorum-Himalaya region under different glacier coverage scenarios. J. Hydrol. 2008, 355, 148-163. [CrossRef]

2. Beniston, M. Climatic Change in Mountain Regions: A Review of Possible Impacts. Clim. Chang. 2003, 59, 5-31. [CrossRef]

3. Descamps, S.; Aars, J.; Fuglei, E.; Kovacs, K.M.; Lydersen, C.; Pavlova, O.; Pedersen, Å.Ø.; Ravolainen, V.; Strøm, H. Climate change impacts on wildlife in a High Arctic archipelago-Svalbard, Norway. Glob. Chang. Biol. 2016. [CrossRef] [PubMed]

4. Hansen, G.; Cramer, W. Global distribution of observed climate change impacts. Nat. Clim. Chang. 2015, 5, 182-185. [CrossRef]

5. Parmesan, C. Ecological and Evolutionary Responses to Recent Climate Change. Annu. Rev. Ecol. Evol. Syst. 2006, 37, 637-669. [CrossRef]

6. Van Aalst, M.K. The impacts of climate change on the risk of natural disasters. Disasters 2006, 30, 5-18. [CrossRef] [PubMed]

7. Vörösmarty, C.J.; Green, P.; Salisbury, J.; Lammers, R.B. Global Water Resources: Vulnerability from Climate Change and Population Growth. Science 2000, 289, 284-288. [CrossRef] [PubMed] 
8. Walther, G.-R.; Post, E.; Convey, P.; Menzel, A.; Parmesan, C.; Beebee, T.J.C.; Fromentin, J.-M.; Hoegh-Guldberg, O.; Bairlein, F. Ecological responses to recent climate change. Nature 2002, 416, 389-395. [CrossRef] [PubMed]

9. Xu, J.C.; Grumbine, R.E.; Shrestha, A.; Eriksson, M.; Yang, X.F.; Wang, Y.; Wilkes, A. The Melting Himalayas: Cascading Effects of Climate Change on Water, Biodiversity, and Livelihoods. Conserv. Biol. 2009, 23, 520-530. [CrossRef] [PubMed]

10. Stocker, T.F.; Qin, D.; Plattner, G.K.; Tignor, M.; Allen, S.K.; Boschung, J.; Nauels, A.; Xia, Y.; Bex, B.; Midgley, B.M. Working Group I Contribution to the IPCC Fifth Assessment Report (AR5), Climate Change 2013: The Physical Science Basis; Cambridge University Press: Cambridge, UK, 2013.

11. Brown, R.D.; Robinson, D.A. Northern Hemisphere spring snow cover variability and change over 1922-2010 including an assessment of uncertainty. Cryosphere 2011, 5, 219-229. [CrossRef]

12. Chand, P.; Sharma, M.C. Glacier changes in the Ravi basin, North-Western Himalaya (India) during the last four decades (1971-2010/13). Glob. Planet. Chang. 2015, 135, 133-147. [CrossRef]

13. Comiso, J.C.; Parkinson, C.L.; Gersten, R.; Stock, L. Accelerated decline in the Arctic sea ice cover. Geophys. Res. Lett. 2008, 35, L01703. [CrossRef]

14. Dyurgerov, M.B.; Meier, M.F. Glaciers and the Changing Earth System: A 2004 Snapshot; Institute of Arctic and Alpine Research, University of Colorado Boulder: Boulder, CO, 2005.

15. Hanna, E.; Navarro, F.J.; Pattyn, F.; Domingues, C.M.; Fettweis, X.; Ivins, E.R.; Nicholls, R.J.; Ritz, C.; Smith, B.; Tulaczyk, S.; et al. Ice-sheet mass balance and climate change. Nature 2013, 498, 51-59. [CrossRef] [PubMed]

16. Kaser, G.; Cogley, J.G.; Dyurgerov, M.B.; Meier, M.F.; Ohmura, A. Mass balance of glaciers and ice caps: Consensus estimates for 1961-2004. Geophys. Res. Lett. 2006, 33. [CrossRef]

17. Stroeve, J.C.; Markus, T.; Boisvert, L.; Miller, J.; Barrett, A. Changes in Arctic melt season and implications for sea ice loss. Geophys. Res. Lett. 2014, 14, 1216-1225. [CrossRef]

18. Tian, H.-Z.; Yang, T.-B.; Lv, H.; Li, C.-X.; He, Y.-B. Climate change and glacier area variations in China during the past half century. J. Mt. Sci. 2016, 13, 1345-1357. [CrossRef]

19. White, A.; Copland, L. Decadal-Scale Variations in Glacier Area Changes Across the Southern Patagonian Icefield Since the 1970s. Arct. Antarct. Alp. Res. 2015, 47, 147-167. [CrossRef]

20. Arnell, N.W.; Gosling, S.N. The impacts of climate change on river flood risk at the global scale. Clim. Chang. 2016, 134, 387-401. [CrossRef]

21. Bouwer, L.M. Have Disaster Losses Increased Due to Anthropogenic Climate Change? Bull. Am. Meteorol. Soc. 2011, 92, 39-46. [CrossRef]

22. Ciscar, J.-C.; Iglesias, A.; Feyen, L.; Szabó, L.; Van Regemorter, D.; Amelung, B.; Nicholls, R.; Watkiss, P.; Christensen, O.B.; Dankers, R.; et al. Physical and economic consequences of climate change in Europe. Proc. Natl. Acad. Sci. USA 2011, 108, 2678-2683. [CrossRef] [PubMed]

23. Gardner, A.S.; Moholdt, G.; Cogley, J.G.; Wouters, B.; Arendt, A.A.; Wahr, J.; Berthier, E.; Hock, R.; Pfeffer, W.T.; Kaser, G.; et al. A Reconciled Estimate of Glacier Contributions to Sea Level Rise: 2003 to 2009. Science 2013, 340, 852-857. [CrossRef] [PubMed]

24. Herring, S.C.; Hoerling, M.P.; Kossin, J.P.; Peterson, T.C.; Stott, P.A. Explaining Extreme Events of 2014 from a Climate Perspective. Bull. Am. Meteorol. Soc. 2015, 96, S1-S172. [CrossRef]

25. Mann, M.E.; Gleick, P.H. Climate change and California drought in the 21st century. Proc. Natl. Acad. Sci. USA 2015, 112, 3858-3859. [CrossRef] [PubMed]

26. Patz, J.A.; Campbell-Lendrum, D.; Holloway, T.; Foley, J.A. Impact of regional climate change on human health. Nature 2005, 438, 310-317. [CrossRef] [PubMed]

27. Bishop, M.P.; Shroder, J.F.; Ali, G.; Bush, A.B.G.; Haritashya, U.K.; Roohi, R.; Sarikaya, M.A.; Weihs, B.J. Remote Sensing of Glaciers in Afghanistan and Pakistan. In Global Land Ice Measurements from Space; Kargel, S.J., Leonard, J.G., Bishop, P.M., Kääb, A., Raup, H.B., Eds.; Springer: Berlin/Heidelberg, Germany, 2014; pp. 509-548.

28. Gardelle, J.; Berthier, E.; Arnaud, Y. Slight mass gain of Karakoram glaciers in the early twenty-first century. Nat. Geosci. 2012, 5, 322-325. [CrossRef]

29. Gardelle, J.; Berthier, E.; Arnaud, Y.; Kääb, A. Region-wide glacier mass balances over the Pamir-KarakoramHimalaya during 1999-2011. Cryosphere 2013, 7, 1263-1286. [CrossRef]

30. Hewitt, K. The Karakoram Anomaly? Glacier Expansion and the 'Elevation Effect', Karakoram Himalaya. Mt. Res. Dev. 2005, 25, 332-340. [CrossRef] 
31. Kääb, A.; Treichler, D.; Nuth, C.; Berthier, E. Brief Communication: Contending estimates of 2003-2008 glacier mass balance over the Pamir-Karakoram-Himalaya. Cryosphere 2015, 9, 557-564. [CrossRef]

32. Minora, U.; Bocchiola, D.; D'Agata, C.; Maragno, D.; Mayer, C.; Lambrecht, A.; Vuillermoz, E.; Senese, A.; Compostella, C.; Smiraglia, C.; et al. Glacier area stability in the Central Karakoram National Park (Pakistan) in 2001-2010: The "Karakoram Anomaly" in the spotlight. Prog. Phys. Geogr. 2016, 40, 629-660. [CrossRef]

33. Quincey, D.J.; Glasser, N.F.; Cook, S.J.; Luckman, A. Heterogeneity in Karakoram glacier surges. J. Geophys. Res. Earth Surf. 2015, 120, 1288-1300. [CrossRef]

34. Shroder, J.F.; Bishop, M.P. Glaciers of Pakistan; United States Government Printing Office: Washington, DC, USA, 2010.

35. Cogley, J.G. Present and future states of Himalaya and Karakoram glaciers. Ann. Glaciol. 2011, 52, 69-73. [CrossRef]

36. Cogley, J.G.; Kargel, J.S.; Kaser, G.; Van der Veen, C. Tracking the source of glacier misinformation. Science 2010, 327, 522. [CrossRef] [PubMed]

37. Cruz, R.V.; Harasawa, H.; Lal, M.; Wu, S.; Anokhin, Y.; Punsalmaa, B.; Honda, Y.; Jafari, M.; Li, C.; Huu Ninh, N. Climate Change 2007: Impacts, Adaptation and Vulnerability. Contribution of Working Group II to the Fourth Assessment Report of the Intergovernmental Panel on Climate Change; Cambridge University Press: Cambridge, UK, 2007.

38. Chaturvedi, R.; Kulkarni, A.; Karyakarte, Y.; Joshi, J.; Bala, G. Glacial mass balance changes in the Karakoram and Himalaya based on CMIP5 multi-model climate projections. Clim. Chang. 2014, 123, 315-328. [CrossRef]

39. Bolch, T.; Kulkarni, A.; Kaab, A.; Huggel, C.; Paul, F.; Cogley, J.G.; Frey, H.; Kargel, J.S.; Fujita, K.; Scheel, M.; et al. The State and Fate of Himalayan Glaciers. Science 2012, 336, 310-314. [CrossRef] [PubMed]

40. Nuimura, T.; Sakai, A.; Taniguchi, K.; Nagai, H.; Lamsal, D.; Tsutaki, S.; Kozawa, A.; Hoshina, Y.; Takenaka, S.; Omiya, S.; et al. The GAMDAM glacier inventory: A quality-controlled inventory of Asian glaciers. Cryosphere 2015, 9, 849-864. [CrossRef]

41. Paul, F.; Barry, R.G.; Cogley, J.G.; Frey, H.; Haeberli, W.; Ohmura, A.; Ommanney, C.S.L.; Raup, B.; Rivera, A.; Zemp, M. Recommendations for the compilation of glacier inventory data from digital sources. Ann. Glaciol. 2009, 50, 119-126. [CrossRef]

42. Paul, F.; Bolch, T.; Kaab, A.; Nagler, T.; Nuth, C.; Scharrer, K.; Shepherd, A.; Strozzi, T.; Ticconi, F.; Bhambri, R.; et al. The glaciers climate change initiative: Methods for creating glacier area, elevation change and velocity products. Remote. Sens. Environ. 2015, 162, 408-426. [CrossRef]

43. Raup, B.; Kääb, A.; Kargel, J.S.; Bishop, M.P.; Hamilton, G.; Lee, E.; Paul, F.; Rau, F.; Soltesz, D.; Khalsa, S.J.S.; et al. Remote sensing and GIS technology in the Global Land Ice Measurements from Space (GLIMS) Project. Comput. Geosci. 2007, 33, 104-125. [CrossRef]

44. Bishop, M.P.; Bonk, R.; Kamp, U.; Shroder, J.F. Terrain analysis and data modeling for alpine glacier mapping. Polar Geogr. 2001, 25, 182-201. [CrossRef]

45. Kargel, J.S.; Leonard, G.J.; Bishop, M.P.; Kääb, A.; Raup, B.H. Global Land Ice Measurements from Space; Springer: Berlin/Heidelberg, Germany, 2014; p. 876.

46. Quincey, D.J.; Bishop, M.P.; Kääb, A.; Berthier, E.; Flach, B.; Bolch, T.; Buchroithner, M.; Kamp, U.; Khalsa, S.J.S.; Toutin, T. Digital terrain modeling and glacier topographic characterization. In Global Land Ice Measurements from Space; Springer: Berlin/Heidelberg, Germany, 2014; pp. 113-144.

47. Bishop, M.P.; Dobreva, I.D. Geomorphometry and Mountain Geodynamics: Issues of Scale and Complexity. In Integrating Scale in Remote Sensing and GIS; CRC Press: New York, NY, USA, 2016; pp. 189-228.

48. Bishop, M.P.; James, L.A.; Shroder, J.F.; Walsh, S.J. Geospatial technologies and digital geomorphological mapping: Concepts, issues and research. Geomorphology 2012, 137, 5-26. [CrossRef]

49. Archer, D.R.; Fowler, H.J. Spatial and temporal variations in precipitation in the Upper Indus Basin, global teleconnections and hydrological implications. Hydrol. Earth Syst. Sci. 2004, 8, 47-61. [CrossRef]

50. Fowler, H.; Archer, D. Conflicting signals of climatic change in the Upper Indus Basin. J. Clim. 2006, 19, 4276-4293. [CrossRef]

51. Afzal, M.; Haroon, M.; Rana, A.; Imran, A. Influence of North Atlantic oscillations and Southern oscillations on winter precipitation of Northern Pakistan. Pak. J. Meteorol. 2013, 9, 1-8.

52. Sevestre, H.; Benn, D.I. Climatic and geometric controls on the global distribution of surge-type glaciers: Implications for a unifying model of surging. J. Glaciol. 2015, 61, 646-662. [CrossRef] 
53. Bishop, M.P.; Bush, A.G.; Furfaro, R.; Gillespie, A.; Hall, D.; Haritashya, U.; Shroder, J., Jr. Theoretical Foundations of Remote Sensing for Glacier Assessment and Mapping. In Global Land Ice Measurements from Space; Kargel, J.S., Leonard, G.J., Bishop, M.P., Kääb, A., Raup, B.H., Eds.; Springer: Berlin/Heidelberg, Germany, 2014; pp. 23-52.

54. Bishop, M.P.; Shroder, J.F., Jr.; Bonk, R.; Olsenholler, J. Geomorphic change in high mountains: A western Himalayan perspective. Glob. Planet. Chang. 2002, 32, 311-329. [CrossRef]

55. Seong, Y.B.; Owen, L.A.; Bishop, M.P.; Bush, A.; Clendon, P.; Copland, L.; Finkel, R.; Kamp, U.; Shroder, J.F. Quaternary glacial history of the central karakoram. Quat. Sci. Rev. 2007, 26, 3384-3405. [CrossRef]

56. Bishop, M.P.; Bush, A.B.G.; Copland, L.; Kamp, U.; Owen, L.A.; Seong, Y.B.; Shroder, J.F., Jr. Climate Change and Mountain Topographic Evolution in the Central Karakoram, Pakistan. Ann. Assoc. Am. Geogr. 2010, 100, 772-793. [CrossRef]

57. Collier, E.; Nicholson, L.; Brock, B.; Maussion, F.; Essery, R.; Bush, A. Representing moisture fluxes and phase changes in glacier debris cover using a reservoir approach. Cryosphere 2014, 8, 1429-1444. [CrossRef]

58. Collier, E.; Maussion, F.; Nicholson, L.I.; Mölg, T.; Immerzeel, W.W.; Bush, A.B.G. Impact of debris cover on glacier ablation and atmosphere-glacier feedbacks in the Karakoram. Cryosphere 2015, 9, 1617-1632. [CrossRef]

59. Scherler, D.; Bookhagen, B.; Strecker, M.R. Spatially variable response of Himalayan glaciers to climate change affected by debris cover. Nat. Geosci. 2011, 4, 156-159. [CrossRef]

60. Arendt, A.; Bliss, A.; Bolch, T.; Cogley, J.G.; Gardner, A.S.; Hagen, J.-O.; Hock, R.; Huss, M.; Kaser, G.; Kienholz, C.; et al. Randolph Glacier Inventory-A Dataset of Global Glacier Outlines: Version 3.2; Global Land Ice Measurements from Space: Boulder, CO, USA, 2012.

61. Hewitt, K. Glacier Change, Concentration, and Elevation Effects in the Karakoram Himalaya, Upper Indus Basin. Mt. Res. Dev. 2011, 31, 188-200. [CrossRef]

62. Mihalcea, C.; Mayer, C.; Diolaiuti, G.; D'Agata, C.; Smiraglia, C.; Lambrecht, A.; Vuillermoz, E.; Tartari, G. Spatial distribution of debris thickness and melting from remote-sensing and meteorological data, at debris-covered Baltoro glacier, Karakoram, Pakistan. Ann. Glaciol. 2008, 48, 49-57. [CrossRef]

63. Forsythe, N.; Blenkinsop, S.; Fowler, H. Exploring objective climate classification for the Himalayan arc and adjacent regions using gridded data sources. Earth Syst. Dyn. 2015, 6, 311. [CrossRef]

64. Cannon, F.; Carvalho, L.M.; Jones, C.; Bookhagen, B. Multi-annual variations in winter westerly disturbance activity affecting the Himalaya. Clim. Dyn. 2015, 44, 441-455. [CrossRef]

65. Cannon, F.; Carvalho, L.M.; Jones, C.; Norris, J. Winter westerly disturbance dynamics and precipitation in the western Himalaya and Karakoram: A wave-tracking approach. Theor. Appl. Climatol. 2016, 125, $27-44$. [CrossRef]

66. Bush, A.B.G. Pacific sea surface temperature forcing dominates orbital forcing of the early Holocene monsoon. Quat. Res. 2001, 55, 25-32. [CrossRef]

67. Annamalai, H.; Sperber, K.R. South Asian Summer Monsoon Variability in a Changing Climate. In The Monsoons and Climate Change: Observations and Modeling; de Carvalho, V.L.M., Jones, C., Eds.; Springer International Publishing: Cham, The Natherlands, 2016; pp. 25-46.

68. Benn, D.I.; Owen, L.A. The role of the Indian summer monsoon and the mid-latitude westerlies in Himalayan glaciation: Review and speculative discussion. J. Geol. Soc. 1998, 155, 353-363. [CrossRef]

69. Hewitt, K. Glaciers of the Karakoram Himalaya: Glacial Environments, Processes, Hazards and Resourcess; Springer: Dordrecht, The Netherlands, 2014.

70. Mayer, C.; Lambrecht, A.; Belo, M.; Smiraglia, C.; Diolaiuti, G. Glaciological characteristics of the ablation zone of Baltoro glacier, Karakoram, Pakistan. Ann. Glaciol. 2006, 43, 123-131. [CrossRef]

71. Wake, C.P. Glaciochemical investigations as a tool for determining the spatial and seasonal variation of snow accumulation in the central Karakorum, northern Pakistan. Ann. Glaciol. 1989, 13, 279-284. [CrossRef]

72. Harman, J.R. Synoptic Climatology of the Westerlies: Process and Patterns; Association of American Geographers: Washington, DC, USA, 1991.

73. Lang, T.J.; Barros, A.P. Winter storms in the central Himalayas. J. Meteorol. Soc. Jpn. 2004, 82, 829-844. [CrossRef]

74. Filippi, L.; Palazzi, E.; von Hardenberg, J.; Provenzale, A. Multidecadal Variations in the Relationship between the NAO and Winter Precipitation in the Hindu Kush-Karakoram. J. Clim. 2014, 27, 7890-7902. [CrossRef] 
75. Machguth, H. Atmospheric science: Glaciers between two drivers. Nat. Clim. Chang. 2014, 4, 12-13. [CrossRef]

76. Mölg, T.; Maussion, F.; Scherer, D. Mid-latitude westerlies as a driver of glacier variability in monsoonal High Asia. Nat. Clim. Chang. 2014, 4, 68-73. [CrossRef]

77. Roohi, R. Research on global changes in Pakistan. In Developments in Earth Surface Processes; Renato Baudo, G.T., Elisa, V., Eds.; Elsevier: Amsterdam, The Netherlands, 2007; Volume 10, pp. 329-340.

78. Yao, T.; Thompson, L.; Yang, W.; Yu, W.; Gao, Y.; Guo, X.; Yang, X.; Duan, K.; Zhao, H.; Xu, B. Different glacier status with atmospheric circulations in Tibetan Plateau and surroundings. Nat. Clim. Chang. 2012, 2, 663-667. [CrossRef]

79. Ahmad, I.; Ambreen, R.; Sun, Z.; Deng, W. Winter-spring precipitation variability in Pakistan. Am. J. Clim. Chang. 2015, 4, 115. [CrossRef]

80. Bhutiyani, M.R.; Kale, V.S.; Pawar, N.J. Climate change and the precipitation variations in the northwestern Himalaya: 1866-2006. Int. J. Climatol. 2010, 30, 535-548. [CrossRef]

81. Janes, T.J.; Bush, A.B.G. The Role of Atmospheric Dynamics and Climate Change on the Possible Fate of Glaciers in the Karakoram. J. Clim. 2012, 25, 8308-8327. [CrossRef]

82. Clift, P.D.; Plumb, R.A. The Asian Monsoon: Causes, History and Effects; Cambridge University Press: Cambridge, UK, 2008; Volume 270.

83. Bush, A.B.; Prentice, M.L.; Bishop, M.P.; Shroder, J.F., Jr. Modeling global and regional climate systems: Climate forcing and topography. In Geographic Information Science and Mountain Geomorphology; Springer Science \& Business Media: Berlin, Germany, 2004; pp. 403-424.

84. Mayer, C.; Lambrecht, A.; Oerter, H.; Schwikowski, M.; Vuillermoz, E.; Frank, N.; Diolaiuti, G. Accumulation Studies at a High Elevation Glacier Site in Central Karakoram. Adv. Meteorol. 2014, 12. [CrossRef]

85. Zafar, M.U.; Ahmed, M.; Rao, M.P.; Buckley, B.M.; Khan, N.; Wahab, M.; Palmer, J. Karakorum temperature out of phase with hemispheric trends for the past five centuries. Clim. Dyn. 2016, 46, 1943-1952. [CrossRef]

86. Shekhar, M.S.; Chand, H.; Kumar, S.; Srinivasan, K.; Ganju, A. Climate-change studies in the western Himalaya. Ann. Glaciol. 2010, 51, 105-112. [CrossRef]

87. Raghavan, K. Tibetan anticyclone and tropical easterly jet. Pure Appl. Geophys. 1973, 110, 2130-2142. [CrossRef]

88. Yanai, M.; Wu, G.-X. Effects of the Tibetan Plateau. In The Asian Monsoon; Springer: Berlin/Heidelberg, Germany, 2006; pp. 513-549.

89. Diaz, H.F.; Markgraf, V. El Niño and the Southern Oscillation: Multiscale Variability and Global and Regional Impacts; Cambridge University Press: Cambridge, UK, 2000.

90. Bush, A.B.G. Extratropical Influences on the El Niño-Southern Oscillation through the Late Quaternary. J. Clim. 2007, 20, 788-800. [CrossRef]

91. Webster, P.J.; Yang, S. Monsoon and Enso: Selectively Interactive Systems. Q. J. R. Meteorol. Soc. 1992, 118, 877-926. [CrossRef]

92. Krishnamurthy, V.; Kirtman, B.P. Relation between Indian Monsoon Variability and SST. J. Clim. 2009, 22, 4437-4458. [CrossRef]

93. Kumar, K.K.; Rajagopalan, B.; Cane, M.A. On the weakening relationship between the Indian monsoon and ENSO. Science 1999, 284, 2156-2159. [CrossRef] [PubMed]

94. Gill, E.C.; Rajagopalan, B.; Molnar, P. Subseasonal variations in spatial signatures of ENSO on the Indian summer monsoon from 1901 to 2009. J. Geophys. Res. Atmos. 2015, 120, 8165-8185. [CrossRef]

95. Veettil, B.K.; Bianchini, N.; Bremer, U.F.; Maier, É.L.B.; Simões, J.C. Recent variations of supraglacial lakes on the Baltoro Glacier in the central Karakoram Himalaya and its possible teleconnections with the pacific decadal oscillation. Geocarto Int. 2016, 31, 109-119. [CrossRef]

96. Dimri, A.P. Relationship between ENSO phases with Northwest India winter precipitation. Int. J. Climatol. 2013, 33, 1917-1923. [CrossRef]

97. Mantua, N.J.; Hare, S.R.; Zhang, Y.; Wallace, J.M.; Francis, R.C. A Pacific Interdecadal Climate Oscillation with Impacts on Salmon Production. Bull. Am. Meteorol. Soc. 1997, 78, 1069-1079. [CrossRef]

98. Newman, M.; Alexander, M.A.; Ault, T.R.; Cobb, K.M.; Deser, C.; Lorenzo, E.D.; Mantua, N.J.; Miller, A.J.; Minobe, S.; Nakamura, H.; et al. The Pacific Decadal Oscillation, Revisited. J. Clim. 2016, 29, 4399-4427. [CrossRef]

99. Krishnamurthy, L.; Krishnamurthy, V. Influence of PDO on South Asian summer monsoon and monsoon-ENSO relation. Clim. Dyn. 2014, 42, 2397-2410. [CrossRef] 
100. Gadgil, S.; Vinayachandran, P.N.; Francis, P.A.; Gadgil, S. Extremes of the Indian summer monsoon rainfall, ENSO and equatorial Indian Ocean oscillation. Geophys. Res. Lett. 2004, 31. [CrossRef]

101. Maity, R.; Nagesh Kumar, D. Bayesian dynamic modeling for monthly Indian summer monsoon rainfall using El Niño-Southern Oscillation (ENSO) and Equatorial Indian Ocean Oscillation (EQUINOO). J. Geophys. Res. Atmos. 2006, 111, D07104. [CrossRef]

102. Cuffey, K.M.; Paterson, W.S.B. Physics of Glaciers; Academic Press: Amsterdam, The Netherlands, 2010.

103. Collier, E.; Molg, T.; Maussion, F.; Scherer, D.; Mayer, C.; Bush, A.B.G. High-resolution interactive modelling of the mountain glacier-atmosphere interface: An application over the Karakoram. Cryosphere 2013, 7, 779-795. [CrossRef]

104. Fernández, A.; Mark, B.G. Modeling modern glacier response to climate changes along the Andes Cordillera: A multiscale review. J. Adv. Model. Earth Syst. 2016. [CrossRef]

105. Searle, M.P. Geology and Tectonics of the Karakoram Mountains; John Wiley \& Sons Inc.: New York, NY, USA, 1991.

106. Bishop, M.P.; Shroder, J.F., Jr.; Hickman, B.L.; Copland, L. Scale-dependent analysis of satellite imagery for characterization of glacier surfaces in the Karakoram Himalaya. Geomorphology 1998, 21, 217-232. [CrossRef]

107. Copland, L.; Pope, S.; Bishop, M.P.; Shroder, J.F.; Clendon, P.; Bush, A.; Kamp, U.; Seong, Y.B.; Owen, L.A. Glacier velocities across the central Karakoram. Ann. Glaciol. 2009, 50, 41-49. [CrossRef]

108. Gerlitz, L.; Conrad, O.; Böhner, J. Large-scale atmospheric forcing and topographic modification of precipitation rates over High Asia-a neural-network-based approach. Earth Syst. Dyn. 2015, 6, 61. [CrossRef]

109. Duncan, C.; Masek, J.; Fielding, E. How steep are the Himalaya? Characteristics and implications of along-strike topographic variations. Geology 2003, 31, 75-78. [CrossRef]

110. Bishop, P.; Dobreva, I.; Houser, C. Geospatial science and technology for understanding the complexities of the Critical Zone. In Developments in Earth Surface Processes, Principles and Dynamics of the Critical Zone; Giardino, J.R., Houser, C., Eds.; Elsevier: Amsterdam, The Netherlands, 2015; Volume 19, pp. 523-561.

111. Vaughan, D.G.; Comiso, J.C.; Allison, I.; Carrasco, J.; Kaser, G.; Kwok, R.; Mote, P.; Murray, T.; Paul, F.; Ren, J.; et al. Observations: Cryosphere. In Climate Change 2013: The Physical Science Basis. Contribution of Working Group I to the Fifth Assessment Report of the Intergovernmental Panel on Climate Change; Cambridge University Press: Cambridge, UK, 2013.

112. Fujita, K.; Nuimura, T. Spatially heterogeneous wastage of Himalayan glaciers. Proc. Natl. Acad. Sci. USA 2011, 108, 14011-14014. [CrossRef] [PubMed]

113. Mukul, M.; Srivastava, V.; Jade, S.; Mukul, M. Uncertainties in the Shuttle Radar Topography Mission (SRTM) Heights: Insights from the Indian Himalaya and Peninsula. Sci. Rep. 2017, 7, 41672. [CrossRef] [PubMed]

114. Nuth, C.; Kaab, A. Co-registration and bias corrections of satellite elevation data sets for quantifying glacier thickness change. Cryosphere 2011, 5, 271-290. [CrossRef]

115. Kääb, A.; Berthier, E.; Nuth, C.; Gardelle, J.; Arnaud, Y. Contrasting patterns of early twenty-first-century glacier mass change in the Himalayas. Nature 2012, 488, 495-498. [CrossRef] [PubMed]

116. Mayewski, P.A.; Jeschke, P.A. Himalayan and Trans-Himalayan Glacier Fluctuations Since AD 1812. Arct. Alp. Res. 1979, 11, 267-287. [CrossRef]

117. Owen, L.A.; England, J. Observations on rock glaciers in the Himalayas and Karakoram Mountains of northern Pakistan and India. Geomorphology 1998, 26, 199-213. [CrossRef]

118. Shroder, J.F.; Bishop, M.P.; Copland, L.; Sloan, V.F. Debris-covered Glaciers and Rock Glaciers in the Nanga Parbat Himalaya, Pakistan. Geogr. Ann. Ser. A Phys. Geogr. 2000, 82, 17-31. [CrossRef]

119. Juen, M.; Mayer, C.; Lambrecht, A.; Han, H.; Liu, S. Impact of varying debris cover thickness on ablation: A case study for Koxkar Glacier in the Tien Shan. Cryosphere 2014, 8, 377. [CrossRef]

120. Kraaijenbrink, P.D.A.; Shea, J.M.; Pellicciotti, F.; Jong, S.M.D.; Immerzeel, W.W. Object-based analysis of unmanned aerial vehicle imagery to map and characterise surface features on a debris-covered glacier. Remote Sens. Environ. 2016, 186, 581-595. [CrossRef]

121. Bishop, M.P.; Shroder, J.F.; Ward, J.L. SPOT multispectral analysis for producing supraglacial debris-load estimates for Batura glacier, Pakistan. Geocarto Int. 1995, 10, 81-90. [CrossRef]

122. Benn, D.I.; Bolch, T.; Hands, K.; Gulley, J.; Luckman, A.; Nicholson, L.I.; Quincey, D.; Thompson, S.; Toumi, R.; Wiseman, S. Response of debris-covered glaciers in the Mount Everest region to recent warming, and implications for outburst flood hazards. Earth Sci. Rev. 2012, 114, 156-174. [CrossRef] 
123. Rowan, A.V.; Egholm, D.L.; Quincey, D.J.; Glasser, N.F. Modelling the feedbacks between mass balance, ice flow and debris transport to predict the response to climate change of debris-covered glaciers in the Himalaya. Earth Planet. Sci. Lett. 2015, 430, 427-438. [CrossRef]

124. Reznichenko, N.; Davies, T.; Shulmeister, J.; McSaveney, M. Effects of debris on ice-surface melting rates: An experimental study. J. Glaciol. 2010, 56, 384-394. [CrossRef]

125. Egholm, D.L.; Knudsen, M.F.; Clark, C.D.; Lesemann, J.E. Modeling the flow of glaciers in steep terrains: The integrated second-order shallow ice approximation (iSOSIA). J. Geophys. Res. Earth Surf. 2011, 116. [CrossRef]

126. Bhardwaj, A.; Joshi, P.K.; Snehmani; Singh, M.K.; Sam, L.; Gupta, R.D. Mapping debris-covered glaciers and identifying factors affecting the accuracy. Cold Reg. Sci. Technol. 2014, 106, 161-174. [CrossRef]

127. Carenzo, M.; Pellicciotti, F.; Mabillard, J.; Reid, T.; Brock, B.W. An enhanced temperature index model for debris-covered glaciers accounting for thickness effect. Adv. Water Res. 2016, 94, 457-469. [CrossRef] [PubMed]

128. Ghosh, S.; Pandey, A.C.; Nathawat, M.S. Mapping of debris-covered glaciers in parts of the Greater Himalaya Range, Ladakh, western Himalaya, using remote sensing and GIS. J. Appl. Remote Sens. 2014, 8, 18. [CrossRef]

129. Khan, A.; Naz, B.S.; Bowling, L.C. Separating snow, clean and debris covered ice in the Upper Indus Basin, Hindukush-Karakoram-Himalayas, using Landsat images between 1998 and 2002. J. Hydrol. 2015, 521, 46-64. [CrossRef]

130. Mihalcea, C.; Mayer, C.; Diolaiuti, G.; Lambrecht, A.; Smiraglia, C.; Tartari, G. Ice ablation and meteorolopical conditions on the debris-covered area of Baltoro glacier, Karakoram, Pakistan. Ann. Glaciol. 2006, 43, $292-300$. [CrossRef]

131. Veettil, B.K.; Franz Bremer, U.; Efrain Bica Grondona, A.; Florencio De Souza, S. Recent changes occurred in the terminus of the Debris-covered Bilafond Glacier in the Karakoram Himalayas using remotely sensed images and digital elevation models (1978-2011). J. Mt. Sci. 2014, 11, 398-406. [CrossRef]

132. Casey, K.; Kääb, A. Estimation of Supraglacial Dust and Debris Geochemical Composition via Satellite Reflectance and Emissivity. Remote Sens. 2012, 4, 2554-2575. [CrossRef]

133. Casey, K.A.; Kääb, A.; Benn, D.I. Geochemical characterization of supraglacial debris via in situ and optical remote sensing methods: A case study in Khumbu Himalaya, Nepal. Cryosphere 2012, 6, 85-100. [CrossRef]

134. Basnett, S.; Kulkarni, A.V.; Bolch, T. The influence of debris cover and glacial lakes on the recession of glaciers in Sikkim Himalaya, India. J. Glaciol. 2013, 59, 1035-1046. [CrossRef]

135. Buri, P.; Pellicciotti, F.; Steiner, J.F.; Miles, E.S.; Immerzeel, W.W. A grid-based model of backwasting of supraglacial ice cliffs on debris-covered glaciers. Ann. Glaciol. 2016, 57, 199-211. [CrossRef]

136. Han, H.; Wang, J.; Wei, J.; Liu, S. Backwasting rate on debris-covered Koxkar glacier, Tuomuer mountain, China. J. Glaciol. 2010, 56, 287-296. [CrossRef]

137. Reid, T.; Brock, B. Assessing ice-cliff backwasting and its contribution to total ablation of debris-covered Miage glacier, Mont Blanc massif, Italy. J. Glaciol. 2014, 60, 3-13. [CrossRef]

138. Sakai, A.; Nakawo, M.; Fujita, K. Distribution Characteristics and Energy Balance of Ice Cliffs on Debris-Covered Glaciers, Nepal Himalaya. Arct. Antarct. Alp. Res. 2002, 34, 12-19. [CrossRef]

139. Sakai, A.; Nakawo, M.; Fujita, K. Melt rate of ice cliffs on the Lirung Glacier, Nepal Himalayas, 1996. Bull. Glacier Res. 1998, 16, 57-66.

140. Sakai, A.; Takeuchi, N.; Fujita, K.; Nakawo, M. Role of supraglacial ponds in the ablation process of a debris-covered glacier in the Nepal Himalayas. In Proceedings of the Debris Covered Glaciers, Seattle, WA, USA, 13-15 September 2000; IAHS Publication: Seattle, WA, USA, 2000.; pp. 119-130.

141. Kirkbride, M.P. The temporal significance of transitions from melting to calving termini at glaciers in the central Southern Alps of New Zealand. Holocene 1993, 3, 232-240. [CrossRef]

142. Kargel, J.; Leonard, G.; Shugar, D.; Haritashya, U.; Bevington, A.; Fielding, E.; Fujita, K.; Geertsema, M.; Miles, E.; Steiner, J. Geomorphic and geologic controls of geohazards induced by Nepal's 2015 Gorkha earthquake. Science 2016, 351, aac8353. [CrossRef] [PubMed]

143. Reynolds, J.M. On the formation of supraglacial lakes on debris-covered glaciers. In Proceedings of the Debris Covered Glaciers, Seattle, WA, USA, 13-15 September 2000; IAHS Publication: Seattle, WA, USA, 2000; pp. 153-164. 
144. Song, C.; Sheng, Y.; Ke, L.; Nie, Y.; Wang, J. Glacial lake evolution in the southeastern Tibetan Plateau and the cause of rapid expansion of proglacial lakes linked to glacial-hydrogeomorphic processes. J. Hydrol. 2016, 540, 504-514. [CrossRef]

145. Sakai, A.; Fujita, K. Formation conditions of supraglacial lakes on debris-covered glaciers in the Himalaya. J. Glaciol. 2010, 56, 177-181. [CrossRef]

146. Quincey, D.J.; Copland, L.; Mayer, C.; Bishop, M.; Luckman, A.; Belo, M. Ice velocity and climate variations for Baltoro Glacier, Pakistan. J. Glaciol. 2009, 55, 1061-1071. [CrossRef]

147. Scherler, D.; Strecker, M.R. Large surface velocity fluctuations of Biafo Glacier, central Karakoram, at high spatial and temporal resolution from optical satellite images. J. Glaciol. 2012, 58, 569-580. [CrossRef]

148. Quincey, D.J.; Braun, M.; Glasser, N.F.; Bishop, M.P.; Hewitt, K.; Luckman, A. Karakoram glacier surge dynamics. Geophys. Res. Lett. 2011, 38, L18504. [CrossRef]

149. Dehecq, A.; Gourmelen, N.; Trouve, E. Deriving large-scale glacier velocities from a complete satellite archive: Application to the Pamir-Karakoram-Himalaya. Remote Sens. Environ. 2015, 162, 55-66. [CrossRef]

150. Harbor, J.M. Numerical modeling of the development of U-shaped valleys by glacial erosion. Geol. Soc. Am. Bull. 1992, 104, 1364-1375. [CrossRef]

151. Koppes, M.; Hallet, B.; Rignot, E.; Mouginot, J.; Wellner, J.S.; Boldt, K. Observed latitudinal variations in erosion as a function of glacier dynamics. Nature 2015, 526, 100-103. [CrossRef] [PubMed]

152. Derbyshire, E.; Owen, L.A. Quaternary glacial history of the Karakoram Mountains and northwest Himalayas: A review. Quat. Int. 1997, 38, 85-102. [CrossRef]

153. Owen, L.A.; Finkel, R.C.; Caffee, M.W.; Gualtieri, L. Timing of multiple late Quaternary glaciations in the Hunza Valley, Karakoram Mountains, northern Pakistan: Defined by cosmogenic radionuclide dating of moraines. Geol. Soc. Am. Bull. 2002, 114, 593-604. [CrossRef]

154. Seong, Y.B.; Bishop, M.P.; Bush, A.; Clendon, P.; Copland, L.; Finkel, R.C.; Kamp, U.; Owen, L.A.; Shroder, J.F. Landforms and landscape evolution in the Skardu, Shigar and Braldu Valleys, Central Karakoram. Geomorphology 2009, 103, 251-267. [CrossRef]

155. Copland, L.; Sylvestre, T.; Bishop, M.P.; Shroder, J.F.; Seong, Y.B.; Owen, L.A.; Bush, A.; Kamp, U. Expanded and Recently Increased Glacier Surging in the Karakoram. Arct. Antarct. Alp. Res. 2011, 43, 503-516. [CrossRef]

156. Braun, J.; Simon-Labric, T.; Murray, K.E.; Reiners, P.W. Topographic relief driven by variations in surface rock density. Nat. Geosci. 2014, 7, 534-540. [CrossRef]

157. Dyurgerov, M.B.; Meier, M.F. Twentieth century climate change: Evidence from small glaciers. Proc. Natl. Acad. Sci. USA 2000, 97, 1406-1411. [CrossRef] [PubMed]

158. Corti, S.; Molteni, F.; Branković, Č. Predictability of snow-depth anomalies over Eurasia and associated circulation patterns. Q. J. R. Meteorol. Soc. 2000, 126, 241-262. [CrossRef]

159. L'Heureux, M.L.; Thompson, D.W. Observed relationships between the El Niño-Southern Oscillation and the extratropical zonal-mean circulation. J. Clim. 2006, 19, 276-287. [CrossRef]

160. Steiner, J.F.; Pellicciotti, F. Variability of air temperature over a debris-covered glacier in the Nepalese Himalaya. Ann. Glaciol. 2016, 57, 295-307. [CrossRef]

161. Sharp, M. Surging glaciers behaviour and mechanisms. Prog. Phys. Geogr. 1988, 12, 349-370. [CrossRef]

162. Barrand, N.E.; Murray, T. Multivariate controls on the incidence of glacier surging in the Karakoram Himalaya. Arct. Antarct. Alp. Res. 2006, 38, 489-498. [CrossRef]

163. Hewitt, K. Glacier Surges in Karakoram Himalaya (Central Asia). Can. J. Earth Sci. 1969, 6, 1009-1018. [CrossRef]

164. Hewitt, K. Tributary glacier surges: An exceptional concentration at Panmah Glacier, Karakoram Himalaya. J. Glaciol. 2007, 53, 181-188. [CrossRef]

165. Jiskoot, H.; Boyle, P.; Murray, T. The incidence of glacier surging in Svalbard: Evidence from multivariate statistics. Comput. Geosci. 1998, 24, 387-399. [CrossRef]

166. Jiskoot, H.; Murray, T.; Boyle, P. Controls on the distribution of surge-type glaciers in Svalbard. J. Glaciol. 2000, 46, 412-422. [CrossRef]

167. Fischer, U.H.; Clarke, G.K.C. Review of subglacial hydro-mechanical coupling: Trapridge Glacier, Yukon Territory, Canada. Quat. Int. 2001, 86, 29-43. [CrossRef]

168. Boulton, G.; Hindmarsh, R. Sediment deformation beneath glaciers: Rheology and geological consequences. J. Geophys. Res. Solid Earth 1987, 92, 9059-9082. [CrossRef] 
169. Bahr, D.B.; Pfeffer, W.T.; Sassolas, C.; Meier, M.F. Response time of glaciers as a function of size and mass balance: 1. Theory. J. Geophys. Res. Solid Earth 1998, 103, 9777-9782. [CrossRef]

170. Bolch, T.; Pieczonka, T.; Mukherjee, K.; Shea, J. Brief communication: Glaciers in the Hunza catchment (Karakoram) have been nearly in balance since the 1970s. Cryosphere 2017, 11, 531. [CrossRef] 